\title{
Roberta Magacho Rodrigues
}

\section{Projeto educativo de jovens com perfil socioeconômico filantrópico: o papel da família}

\section{DISSERTAÇÃO DE MESTRADO}

\section{DEPARTAMENTO DE PSICOLOGIA \\ Programa de Pós-Graduação em \\ Psicologia Clínica}




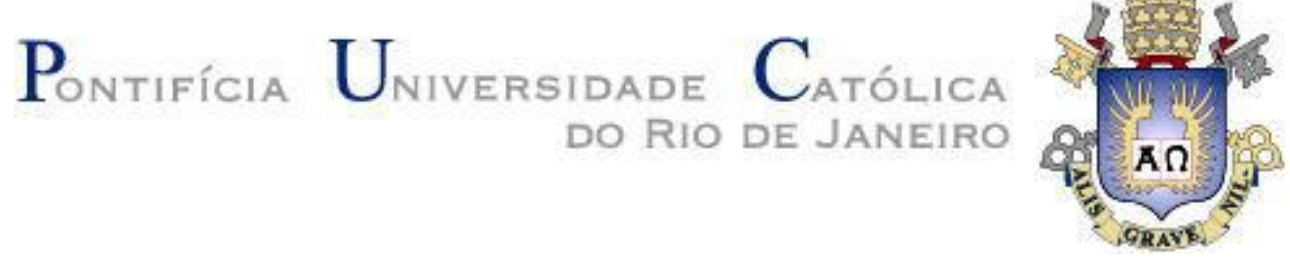

Roberta Magacho Rodrigues

\section{Projeto educativo de jovens com perfil socioeconômico filantrópico:}

o papel da família

Dissertação de Mestrado

Dissertação apresentada como requisito parcial para obtenção do grau de Mestre pelo Programa de Pósgraduação em Psicologia Clínica do Departamento de Psicologia da PUC-Rio.

Orientadora: Prof. Andrea Seixas Magalhães 
Pontifícia Universidade Católica $_{\text {a }}$

Roberta Magacho Rodrigues

\section{Projeto educativo de jovens com perfil socioeconômico filantrópico: \\ o papel da família}

Dissertação apresentada como requisito parcial para obtenção do grau de Mestre pelo Programa de Pós-Graduação em Psicologia (Psicologia Clínica) do Departamento de Psicologia do Centro de Teologia e Ciências Humanas da PUC-Rio. Aprovada pela Comissão Examinadora abaixo assinada.

Profa. Andrea Seixas Magalhães

Orientadora

Departamento de Psicologia - PUC-Rio

Profa. Terezinha Feres-Carneiro

Departamento de Psicologia - PUC-Rio

Profa. Celia Regina Henriques

CCE/PUC-Rio

Profa. Monah Winograd

Coordenadora Setorial de Pós-Graduação

e Pesquisa do Centro de Teologia

e Ciências Humanas - PUC-Rio

Rio de Janeiro, 16 de março de 2017. 
Todos os direitos reservados. É proibida a reprodução total ou parcial do trabalho sem autorização do autor, do orientador e da universidade.

Roberta Magacho Rodrigues

Graduação em Psicologia pela Pontifícia Universidade Católica do Rio de Janeiro (PUC-Rio). Formação em Terapia Comunitária Sistêmica Integrativa pela Universidade Federal do Ceará. Especialização em Terapia de Família e Casal pela Pontifícia Universidade Católica do Rio de Janeiro (PUC-Rio). Pósgraduação em Gestão de Pessoas pela Fundação Getúlio Vargas (FGV). Atua como psicóloga e supervisora no PSICOM (Serviço Comunitário de Orientação Psicológica) da PUC-Rio.

Ficha Catalográfica

Rodrigues, Roberta Magacho

Projeto educativo de jovens com perfil socioeconômico filantrópico : o papel da família / Roberta Magacho Rodrigues ; orientadora: Andrea Seixas Magalhães. - 2017.

72 f. ; $30 \mathrm{~cm}$

Dissertação (mestrado)-Pontifícia Universidade Católica do Rio de Janeiro, Departamento de Psicologia, 2017.

Inclui bibliografia

1. Psicologia - Teses. 2. Família. 3. Transmissão de valores. 4. Projeto educacional. 5. Perfil socioeconômico filantrópico. 6. Universitários. I. Magalhães, Andrea Seixas. II. Pontifícia Universidade Católica do Rio de Janeiro. Departamento de Psicologia. III. Título. 


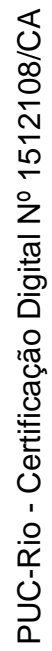

Para meus pais, Patricia e Alvaro, pelo amor e apoio incondicionais. 


\section{Agradecimentos}

À minha orientadora, Andrea Seixas Magalhaes, pelo acolhimento, por ter acreditado em mim, por ter me incentivado e me fortalecido até o final desse trabalho.

Aos membros da banca, que tão gentilmente aceitaram nosso convite.

Às minhas companheiras de equipe: Carla Mendes, Mariana Matos, Ana Franqueira, Debora Sampaio pelas valiosas trocas.

Aos amigos e companheiros de jornada: Jessica, Lucas, Rafael, Renato, Denise, Claudina, Fernanda e Paloma.

Aos mestres que tive ao longo da minha trajetória e que me inspiraram, me ensinaram e confiaram no meu potencial, me fazendo acreditar também em mim: Regina Jardim, Meg de Mesquita, Jean Natividade e Mariângela Monteiro.

Às amigas de uma vida inteira: Daniela Angeli, Diana Montenegro, Nathalia Gadelha e Patricia Fortes por toda a amizade e a força que me deram ao longo desse percurso.

Ao Henrique pelo apoio, pela compreensão, pelo incentivo e pela cumplicidade ao longo desse processo.

Ao meu chefe e Vice-Reitor, Augusto Sampaio, pela confiança no meu trabalho, pela generosidade com minha trajetória acadêmica e pela oportunidade de me permitir trabalhar com aquilo que eu amo.

Ao meu chefe, Cesar Sidonio, por me apoiar e permitir que eu tenha um aprendizado constante sob sua liderança.

À Ana Carolina, parceira de trabalho e amiga, pelas trocas enriquecedoras.

À todos os alunos que participaram dessa pesquisa e também àqueles que inspiraram toda essa pesquisa e que me inspiram diariamente para a realização do meu trabalho.

Aos meus pais, a quem jamais conseguirei agradecer o suficiente, que me ensinaram os valores que carrego comigo, que me incentivam e sempre me proporcionaram um ambiente de confiança e alegria que permitiu que eu internalizasse a crença de que todos nós somos capazes de importantes realizações.

À minha avó, Anna, por todo amor e por me ensinar no convívio com ela, o entusiasmo pela vida e a força para superar as dificuldades e os desafios.

À todos aqueles que, direta ou indiretamente, participaram da construção desse trabalho, obrigada. 


\section{Resumo}

Rodrigues, Roberta Magacho; Magalhães, Andrea Seixas. Projeto educativo de jovens com perfil socioeconômico filantrópico: o papel da família. Rio de Janeiro, 2017. 72p. Dissertação de Mestrado Departamento de Psicologia, Pontifícia Universidade Católica do Rio de Janeiro.

A sociedade brasileira é marcada por grandes desigualdades sociais e os investimentos em educação são apontados como importante estratégia para a transformação dessa realidade. A educação está na pauta de inúmeros programas sociais e frequentemente apresenta-se para as famílias de menor renda como um dos investimentos mais importantes a serem feitos nos filhos na busca de melhores oportunidades de trabalho e de ascensão social. Recentemente, houve grandes avanços nas políticas sociais de inclusão no ensino superior. Devido à ampliação do acesso às universidades brasileiras, cada vez mais os jovens de perfil socioeconômico filantrópico estão sendo inseridos no ensino superior. No presente estudo, foi investigada a percepção do jovem universitário de perfil filantrópico sobre o papel da família no seu projeto educacional por meio de uma pesquisa de campo exploratória com a realização de entrevistas com roteiro semiestruturado com oito alunos universitários de graduação, com perfil socioeconômico filantrópico. As entrevistas foram analisadas por meio do método de análise de conteúdo proposto por Bardin (2011) e do discurso dos sujeitos emergiram sete categorias de análise: educação como valor familiar; influências no projeto educacional; o diploma da família; percepção dos jovens sobre programas sociais; obstáculos e desafios durante a graduação; rede de apoio como suporte e ampliação dos horizontes. Como resultados, destacou-se a forte influência dos valores transmitidos pelas famílias, especialmente do valor da educação, no delineamento de um projeto educacional e na consequente escolha pelo ingresso no ensino superior. Os dados sugerem que, apesar de o projeto educacional ser uma escolha autônoma e individual, as conquistas realizadas por esses jovens são sentidas como conquistas coletivas das famílias. Os programas sociais de inserção receberam avaliação positiva dos participantes, que apontaram ainda uma necessidade de expansão do acesso aos mesmos. Quanto às principais dificuldades ao longo da trajetória acadêmica, foram destacadas as longas distâncias entre residência e universidade, dificuldades na transição do ensino 
médio para o ensino superior e os custos de manutenção e permanência na universidade. Os dados indicaram que, no enfrentamento das dificuldades, os sujeitos contam com suas redes de apoio, incluindo pais, amigos e apoio institucional. A experiência de cursar o ensino superior traz ainda, além da formação acadêmica superior, alguns outros significados para os jovens, como a abertura de novos horizontes, retribuição para a família e o lugar de exemplo perante a comunidade de origem.

\section{Palavras-chave}

Família; transmissão de valores; projeto educacional; perfil socioeconômico filantrópico; programas sociais; universitários. 


\section{Abstract}

Rodrigues, Roberta Magacho; Magalhães, Andrea Seixas (Advisor). Educational Project of young students with philantropic profile: the role of the family. Rio de Janeiro, 2017. 72p. Dissertação de Mestrado Departamento de Psicologia, Pontifícia Universidade Católica do Rio de Janeiro.

Brazilian society is marked by great social inequalities and the investments in education are pointed out as an important strategy to transforming this reality. Education is at the top of the agenda of many social programs and it is often regarded as one of the most important investments to be made on their children by low income families when it comes to pursuing better job opportunities as well as ascending on social status. Recently, there have been substantial advances in social policies which aim to enlarge the access to higher education. Since the access to Brazilian universities is on the increase, more and more philanthropic socioeconomic profile students are being admitted into higher education. In this study, we investigated the perspective of these youngsters on the role of the family in their educational project. Such investigation was carried out through an explanatory field research, which consisted in a semi-structured interview with eight undergraduate students with philanthropic profile. The interviews were analyzed according to the content analysis method, as proposed by Bardin (2011). Seven categories emerged from the subjects' narratives: education as a family value; influences in the educational project; the family diploma; the students' perception of social programs; obstacles and challenges during graduation; support networks to expanding horizons. Thus, the strong influence of family values, especially the value of education, in the shaping of an education project and its consequent choice in entering university stood out. Data suggest that, even though this project is an individual and autonomous choice, these students' achievements are felt like collective accomplishments of their families. The participants evaluated inclusion social programs positively and they also highlighted the need to expanding the access to such programs. As to the main difficulties faced during their academic course, they underlined the long distances from their homes to university campus, the hardship in the transition from high school to higher education and financial permanence of scholarship students. The 
data indicated that when it comes to facing such difficulties, the subjects could count on support networks, including not only their parents and friends, but also institutional support. In addition to achieving higher education, taking an undergraduate course brings some other important meanings to these young students, for instance, the opening of new horizons, the possibility of rewarding their families and becoming a role model to their communities.

\section{Keywords}

Family; transmission of values; educational project; philanthropic socioeconomic profile; social programs; university students. 


\section{Sumário}

1. Introdução

2. O diploma da família: narrativas de jovens universitários com perfil socioeconômico filantrópico

2.1. Método

2.2. Resultados e discussão

2.3. Considerações finais

3. Transformando oportunidades em conquistas:

questões sobre a trajetória acadêmica de universitários bolsistas

3.1. Método

3.2. Resultados e discussão

3.3. Considerações finais

4. Conclusões

5. Referências bibliográficas

Anexos 


\section{Introdução}

O Brasil é um país marcado por grandes desigualdades sociais e problemas econômicos. Os investimentos em educação são apontados como uma alternativa para a solução dessas questões. As famílias, as empresas e o governo investem no desenvolvimento sociocognitivo de crianças e jovens com a perspectiva de verem um retorno social e econômico do capital investido quando esses sujeitos se tornarem profissionais (GOMES \& SOARES, 2013).

A educação está atrelada ao desenvolvimento de uma nação, ao exercício de cidadania, sendo também elemento essencial para tornar a sociedade mais justa, solidária e integrada (SARAIVA \& NUNES, 2011; SANTOS, POLYDORO, SCOTEGAGNA \& LINDEN, 2013). A educação superior contribui para a melhoria da sociedade como um todo, ao formar profissionais qualificados e capazes de exercer papéis e gerar soluções para as necessidades de diversos setores de atividades humanas. Além disso, auxilia na disseminação do conhecimento, a partir de sua aplicação e de seu compartilhamento. A questão da ampliação da oferta de vagas no Ensino Superior no país apresenta-se, portanto, como um elemento crucial para o desenho de cenários futuros do campo educacional e profissional (AMARAL \& OLIVEIRA, 2011).

A busca crescente da população pelo ensino superior se dá, entre outros fatores, devido à necessidade de aquisição de competências para enfrentar um mercado de trabalho cada vez mais instável, mais seletivo e excludente que exige uma qualificação cada vez mais abrangente. Destaca-se também que o interesse pelo ingresso na universidade pode estar relacionado às expectativas de melhoria de vida, crescimento da renda e ascensão social atribuídas a uma escolarização de nível superior (AMARAL \& OLIVEIRA, 2011; FELICETTI, CABRERA \& COSTA-MOROSINI, 2014).

A democratização do acesso à educação superior, particularmente a participação de jovens de baixa renda nesse nível educacional, passou a ganhar espaço na agenda dos governos e da sociedade brasileira apenas nos anos recentes, desencadeando políticas públicas de expansão e ações afirmativas voltadas aos grupos sociais historicamente mais excluídos (NIEROTKA, 2016).

De acordo com GEMAA - Grupo de Estudos Multidisciplinares da Ação Afirmativa (2011): 
“Ações afirmativas são políticas focais que alocam recursos em benefício de pessoas pertencentes a grupos discriminados e vitimados pela exclusão sócio-econômica no passado ou no presente. Trata-se de medidas que têm como objetivo combater discriminações étnicas, raciais, religiosas, de gênero ou de casta, aumentando a participação de minorias no processo político, no acesso à educação, saúde, emprego, bens materiais, redes de proteção social e/ou no reconhecimento cultural".

Sarmento (2008) conceitua políticas de ação afirmativa da seguinte forma:

"são medidas públicas ou privadas, de caráter coercitivo ou não, que visam promover a igualdade substancial por meio da discriminação positiva de pessoas integrantes de grupos que estejam em situação desfavorável e que sejam vítimas de discriminação e estigma social. Elas podem ter focos muito diversificados, como mulheres, os portadores de deficiência, os indígenas ou os afrodescendentes, e incidir nos mais variados campos, como educação superior, acesso a empregos privados ou cargos públicos, reforço à representação política ou preferências na celebração de contratos". (p. 208)

A Pontifícia Universidade Católica do Rio de Janeiro (PUC-Rio) vem implementando, desde 1994, uma política de ação afirmativa com o objetivo de favorecer o acesso de jovens e adultos de camadas populares aos cursos de graduação, prioritariamente estudantes economicamente desfavorecidos (SALVADOR, 2009). Com um amplo programa de bolsas e auxílios, a PUC-Rio permite que jovens de perfil socioeconômico filantrópico ingressem na universidade como bolsistas e escrevam suas próprias trajetórias acadêmicas. O perfil socioeconômico filantrópico é definido de acordo com o valor da renda bruta familiar per capita. A bolsa de estudo integral é concedida a alunos cuja renda familiar mensal per capita não exceda o valor de 1 1/2 (um e meio) salário mínimo (Lei 12.101).

O projeto de vida dos jovens é influenciado pelo projeto educacional e pelo projeto familiar, de acordo com Ribeiro (2010). O projeto educacional, especialmente em famílias com menores possibilidades de acesso à educação, ganha destaque no projeto de vida desses jovens, em busca de alcançarem melhores condições de inserção profissional e, consequentemente, melhores condições socioeconômicas para si e para suas famílias (Reis, 2013). O ingresso no ensino superior parece ampliar as possibilidades de sucesso profissional e 
proporcionar a abertura desses estudantes para novas experiências laborais e pessoais.

O projeto educacional, embora envolva elementos individuais, como a subjetividade de cada sujeito, a sua história pessoal, seus interesses e suas habilidades, é perpassado por outros agentes como o contexto social em que vivem e, principalmente, o grupo familiar ao qual pertencem (STANK, ROTH, MONTEIRO \& MAFFEI, 2014; ALMEIDA \& MAGALHAES, 2011; RIBEIRO, 2010; ANDRADE, 1997).

A influência da família é um processo contínuo de transmissão geracional. Através das relações familiares, são comunicadas representações compartilhadas, valores, crenças, ideais, estereótipos, comportamentos esperados, e os papéis que cada sujeito desempenha dentro do núcleo familiar, bem como aquilo que se espera de cada um (RIBEIRO, 2010; REIS, 2013). Essa transmissão gera um legado, uma herança familiar, que pode vir a se transformar em uma missão a partir da qual o sujeito se vê responsável por cumprir algo que as gerações anteriores não puderam cumprir (BOSZORMENYI-NAGY \& SPARK, 1984; BUCHER-MALUSCHKE, 2008; KROM, 2000).

Em muitas famílias de perfil socioeconômico filantrópico, o estudo tem a função de realização de um empreendimento familiar. Muitos jovens com esse perfil são os primeiros de suas famílias a chegarem a esse nível de instrução (FELICETTI, CABRERA \& COSTA-MOROSINI， 2014; ABDAL \& NAVARRA，2014; SOARES， FRANCISCHETTO， DUTRA，MIRANDA, NOGUEIRA, LEME, ARAUJO \& ALMEIDA, 2014 ). Além de estar realizando a missão familiar, a conquista do diploma traz para o jovem um sentido de conquista que eleva sua autoestima e o coloca, muitas vezes, no lugar de referência, como um exemplo a ser seguido por outras pessoas da família e da comunidade em que vive (FELICETTI , 2014; SARAIVA \& NUNES, 2011).

Ser o primeiro a graduar-se nesse nível de ensino representa, para toda a família, uma mudança de perspectivas e posturas diante dos mais variados aspectos. Entre as mudanças observadas nos jovens que realizam essa trajetória acadêmica e em suas famílias estão a expansão da visão de mundo, a ampliação das possibilidades de crescimento profissional e de prestígio social (ALMEIDA, 2015; MORGIN, 2015; GOMES \& SOARES, 2013; AMARAL \& OLIVEIRA, 2011). 
A jornada acadêmica apresenta também algumas dificuldades para os jovens bolsistas. A transição do ensino médio para o ensino superior é um momento que exige adaptações de diversas naturezas por parte desses estudantes, entre elas uma atitude mais proativa que é exigida na universidade, formas de cobranças diferenciadas e novas relações sociais e institucionais. Além dessas questões, apresentam-se ainda desafios de ordem social e financeira, como as longas distâncias entre o campus universitário e a residência dos estudantes e os custos de manutenção e permanência na universidade (SANTOS, 2012; RIBEIRO \& BOLSONI-SILVA, 2011; BOLSONI-SILVA ET AL, 2010; GOMES \& SOARES, 2013; SANTOS ET AL, 2013; OLIVEIRA \& DIAS, 2013; BARDAGI \& HUTZ, 2008; GUERREIRO-CASANOVA \& POLYDORO, 2010). Para enfrentar esses desafios, os jovens contam com uma ampla rede de apoio que inclui a família, amigos e os próprios recursos institucionais (MORGIN, 2015; OLIVEIRA \& DIAS, 2013; SANTOS, 2012).

Ao longo dos últimos cinco anos trabalhando como psicóloga e coordenadora do PSICOM (Serviço Comunitário de Orientação Psicológica) da Vice-Reitoria para Assuntos Comunitários da PUC-Rio, tenho podido acompanhar a trajetória de vários desses jovens ao longo dos anos de graduação e receber notícias de outros tantos que se formam e mantêm nossa equipe atualizada em relação a seus caminhos profissionais após a formatura. Com muita admiração pelas histórias desses alunos que passaram pelo nosso Serviço, e com o intuito de aprimorar os nossos atendimentos, passei a observar o que parecia ajudar esses estudantes a transporem os obstáculos, se superarem e se manterem em seu objetivo de se formar na universidade. Comecei a perceber que a família aparecia muito no discurso desses sujeitos, bem como um senso de um propósito maior para essa formação acadêmica que ia além da conquista de um diploma.

Neste sentido, o presente estudo pretendeu, como objetivo principal investigar a percepção do jovem universitário de perfil filantrópico sobre o papel da família no seu projeto educacional. Como objetivos específicos, pretendeu-se: discutir o papel da transmissão geracional de valores familiares no projeto educacional desses jovens; investigar a percepção dos sujeitos sobre os programas sociais de inserção para jovens com perfil filantrópico; e pesquisar sobre suas experiências ao longo da graduação. 
Para tanto, foi realizado um estudo exploratório, por meio de entrevistas com oito jovens universitários, com perfil socioeconômico filantrópico, com idades entre 18 e 28 anos, que estão ou estiveram em atendimento no PSICOM (Serviço Comunitário de Orientação Psicológica da PUC-Rio) e que tenham relatado a importância da sua família em sua vida acadêmica. As entrevistas utilizaram roteiro semiestruturado previamente delineado (Anexo A). Para analisar as entrevistas, foi utilizado o método de análise de conteúdo (BARDIN, 2011). Do discurso dos sujeitos emergiram sete categorias de análise: educação como valor familiar; influências no projeto educacional; o diploma da família; percepção dos jovens sobre programas sociais; obstáculos e desafios durante a graduação; rede de apoio como suporte e ampliação dos horizontes.

A discussão dos resultados da pesquisa será apresentada no formato de dois artigos, denominados " $O$ diploma da família: narrativas de jovens universitários com perfil socioeconômico filantrópico" e "Transformando oportunidades em conquistas: questões sobre a trajetória acadêmica de universitários bolsistas". No primeiro artigo, será discutido o papel da transmissão geracional de valores familiares no projeto educacional desses jovens, alunos de graduação com perfil socioeconômico filantrópico, por meio da discussão das categorias educação como valor familiar; influências no projeto educacional e o diploma da família. No segundo artigo, a discussão será em torno da percepção dos sujeitos sobre as políticas sociais de inclusão para jovens com perfil filantrópico e sobre suas experiências ao longo da graduação por meio das seguintes categorias: percepção dos jovens sobre programas sociais; obstáculos e desafios durante a graduação; rede de apoio como suporte; e ampliação dos horizontes. 


\title{
O diploma da família: narrativas de jovens universitários com perfil socioeconômico filantrópico
}

\section{Resumo}

Realizamos ampla pesquisa com o objetivo de investigar a percepção do jovem universitário de perfil filantrópico sobre o papel da família no seu projeto educacional. Foram entrevistados oito jovens. As entrevistas foram analisadas pelo método de análise de conteúdo e das narrativas emergiram sete categorias de análise. Para apresentação e discussão neste trabalho, cujo objetivo específico é discutir o papel da transmissão geracional de valores familiares no projeto educacional desses jovens, destacamos as seguintes categorias: Educação como valor familiar; influências no projeto educacional e o diploma da família. Os resultados apontam para a forte influência dos valores transmitidos pelas famílias, especialmente do valor da educação, no delineamento de um projeto educacional e na consequente escolha pelo ingresso no ensino superior. Apesar de o projeto educacional ser uma escolha autônoma e individual, as conquistas realizadas por esses jovens são sentidas como conquistas coletivas por parte de suas famílias.

Palavras-chave: Família; transmissão de valores; projeto educacional; perfil socioeconômico filantrópico.

\begin{abstract}
We conducted a comprehensive research with the purpose of investigating the perception of the young university student with a philanthropic profile concerning the role of the family in their educational project. We interviewed eight youths six women and two men - and used the content analysis method to assess the results. Seven theme categories emerged from the accounts. In this paper, whose specific purpose is to discuss the role of the generational transmission of family values in the educational project of youths, we focused on the following three categories: education as a family value; influences in the educational project; and the family diploma. The results point toward a strong influence of family values,
\end{abstract}


particularly the value of education, in the shaping of an educational project and the resulting choice of pursuing a higher education. Even though the educational project is an autonomous and individual choice, the achievements of these youths are felt as collective achievements by their families.

Keywords: Family; transmission of values; educational project; philanthropic socioeconomic profile.

Um dos maiores desafios da democracia contemporânea brasileira tem sido o de encontrar respostas políticas capazes de reduzir as desigualdades sociais. O acesso à educação é reconhecido como um dos principais fatores associados ao alcance de melhores oportunidades no mercado de trabalho e, consequentemente, de melhores empregos e salários. A educação está na pauta de inúmeros programas sociais e frequentemente apresenta-se para as famílias de baixa renda como um dos investimentos mais importantes a serem feitos para garantir uma mobilidade social ascendente para os filhos (REIS, 2013; SALVADOR, HERINGER \& OLIVEIRA, 2014).

De acordo com o INEP (Instituto Nacional de Estudos e Pesquisas Educacionais Anísio Teixeira Resumos Técnicos), no período de 2010 a 2013, verifica-se no Brasil um crescimento das matrículas de graduação tanto na categoria pública $(17,6 \%)$ quanto na privada $(13,5 \%)$. Em 2013, houve maior número de ingressos $(80,6 \%)$ na categoria privada. De acordo com o Mapa do Ensino Superior no Brasil (2015), feito pelo SEMESP (Sindicato das mantenedoras de ensino superior), a procedência de alunos matriculados no ensino superior privado continua sendo, predominantemente, de alunos do ensino médio público. Segundo esse relatório, em 2013, 69,7\% dos alunos ingressantes 
no ensino superior privado eram egressos do ensino médio público e apenas $30,3 \%$ do ensino médio privado.

A partir desse cenário político-social de abertura de oportunidades para jovens de classes socioeconômicas mais baixas, como aqueles de perfil socioeconômico filantrópico (Lei 12.101), parece tornar-se possível para esses sujeitos um investimento em um projeto educacional envolvendo o ingresso no ensino superior como uma forma de busca por melhores oportunidades.

No que se refere ao projeto educacional e à escolha vocacional, existem diversos fatores que influenciam essas decisões dos jovens, tanto de caráter individual, quanto coletivo. Com relação àquilo que é individual, podemos citar as convicções políticas e religiosas, expectativas, interesses, valores e crenças. O contexto sociohistórico, político e econômico do país, as características do mercado de trabalho e as expectativas com relação ao papel de um jovem adulto na sociedade são fatores que também influenciam as escolhas e estão no âmbito coletivo. Há, ainda, fatores como a família, os pares, a escola, o histórico educacional do sujeito e a comunidade onde o sujeito vive, que também influenciarão essas escolhas. A interação de todos esses fatores sobredetermina as possibilidades e limites psicossociais que cada um terá na elaboração, no planejamento, na realização e na gestão de seu projeto (FERNANDES \& GONÇALVES, 2012; MANDELLI, SOARES \& LISBOA, 2011; RIBEIRO, 2010).

Considerando que a elaboração de projetos educacionais e as escolhas profissionais são construídas num determinado contexto social e familiar (ALMEIDA \& MAGALHÃES, 2011), torna-se importante pesquisar sobre a influência desses agentes nas decisões dos jovens que ingressam no ensino 
superior. Uma vez que as relações estabelecidas na família de origem representam o alicerce do comportamento futuro dos sujeitos, reconhecer as influências familiares pode enriquecer os membros da família e, ao mesmo tempo, evitar que eles fiquem presos à repetição de histórias da família (PELLEGRINI et al, 2015). Segundo Ribeiro (2010), o projeto de vida do jovem está sobredeterminado pelo projeto familiar e é parte integrante dele através de um processo contínuo de transmissão geracional, realizada de forma intencional ou não nas relações familiares. A transmissão familiar é um tema bastante estudado, tanto por psicólogos quanto por cientistas sociais. As transmissões não ocorrem unicamente em momentos privilegiados, mas estão presentes durante todo o processo de vida dos membros de uma família (CARRETEIRO \& FREIRE, 2006).

A transmissão compreende um processo estruturante sobre a herança genealógica de uma família e ocorre em nível inconsciente, em grande parte. Apesar da evidência de que as experiências na família de origem se fazem presentes na vida do indivíduo, são relativamente poucas as pessoas conscientes acerca de como tais eventos, continuamente, influenciam e controlam seus comportamentos (LISBOA, FERES-CARNEIRO \& MAGALHÃES, 2011).

Os estudos sobre transmissão geracional surgiram a partir da tentativa de explicar os padrões familiares que se repetem de uma geração a outra, ou seja, situações que se reproduzem no seio da família através das gerações. Bowen (1965) desenvolveu tal conceito, nomeando-o de transmissão multigeracional, na tentativa de explicar o processo de repetição de padrões de relacionamento na família. 
De acordo com BOWEN (1965), o processo de transmissão familiar pode começar bem antes de a criança nascer, quando a família começa a idealizar aquele bebê, pensar e fantasiar sobre ele, imaginando o lugar que será ocupado por ele em suas vidas. Os pais projetam nos filhos as suas questões, e esses, por sua vez, irão introjetá-las em maior ou menor grau, muitas vezes direcionando comportamentos de acordo com a expectativa desses pais. Ou seja, o indivíduo, mesmo antes de nascer, já recebe uma projeção familiar e já vem ao mundo inserido em uma história preexistente da qual ele é herdeiro e também prisioneiro.

O processo de transmissão através das gerações é definido por legados, mitos e lealdades que se perpetuam e fazem parte da história familiar, além dos valores transmitidos pela família em interface com o âmbito sociocultural no qual está inserida. Desta forma, a transmissão geracional permite dar continuidade à identidade familiar ao longo do tempo (BACAL, 2013).

Encontramos referências da força da família em sua perpetuação mediante a transmissão de seus legados de geração a geração nas culturas mais diversas. Esse fenômeno de transmissão geracional dá identidade à família e veicula as idiossincrasias e transações que caracterizam o funcionamento familiar da última geração (FALCKE \& WAGNER, 2005; MONTEIRO \& TEIXEIRA, 2011).

O projeto educacional que o sujeito escolhe seguir é, portanto, perpassado por essas influências familiares. Conforme Soares-Lucchiari (1997), os pais constroem projetos para o futuro do filho e desejam que ele corresponda à imagem sobre ele projetada, propondo, muitas vezes, objetivos e investindo o filho da missão de realizar sonhos que os pais não puderam realizar em suas próprias trajetórias. Essa missão, muitas vezes, inclui também a expectativa de que esses filhos venham a realizar conquistas que ajudem a superar a situação 
social familiar. De certa forma, os filhos carregam então a responsabilidade pelo sucesso, prestígio e ascensão social da família.

Em gerações sucessivas de uma família, é comum atribuição precoce de mandato aos seus membros. O peso que a família dá a essa atribuição é que irá determinar o poder e o quanto esse mandato passará a fazer parte do modo de viver do sujeito. A frustração da expectativa familiar, na recusa de cumprir determinado papel ou função, gera sentimentos de abandono e solidão. O indivíduo vive tal experiência como um fracasso e pode defrontar-se com sentimento de culpa e sofrimento que tal desobediência, frequentemente, provoca em termos pessoais e familiares (FALCKE \& WAGNER, 2005).

A partir dessas expectativas familiares, todo ser humano recebe da família uma missão a cumprir, que pode ser passada de forma explícita ou implícita. É como se houvesse expectativas estruturadas a respeito das escolhas que o sujeito fará ao longo de sua vida. Para que esse sujeito não precise ficar preso a esse compromisso de forma passiva, e nem, por outro lado, quebre o sentimento de lealdade familiar (BOSZORMENYI-NAGY \& SPARK, 1984), é necessário que se possa redimensionar os mandatos familiares, buscando um novo sentido para eles através de uma nova contextualização das missões familiares (FILOMENO, 2005).

Apesar da ampliação nas possibilidades de ingresso no ensino superior no Brasil nos últimos anos, através de políticas sociais de acesso, permitindo que jovens de perfil socioeconômico filantrópico cursassem uma faculdade, ainda são poucas as pesquisas realizadas com essa população e sobre as influencias familiares no projeto educativo. O presente estudo pretendeu discutir o papel da transmissão geracional de valores familiares no projeto educacional desses jovens. 


\section{1}

\section{Método}

\section{Participantes}

Participaram desse estudo 8 alunos universitários, de graduação, com perfil socioeconômico filantrópico, com idades entre 18 e 28 anos, que estão ou estiveram em atendimento no PSICOM (Serviço Comunitário de Orientação Psicológica da PUC-Rio) e que tenham relatado anteriormente a importância da sua família em sua vida acadêmica.

As famílias dos participantes apresentaram algumas características similares, como por exemplo, a migração. Dos oito participantes, apenas um tem família de origem do estado do Rio de Janeiro. Todos as outras famílias vieram de estados brasileiros diversos, muitos dos pais em busca de trabalho e alguns de melhores condições de estudo para si. Além disso, as famílias de origem dos participantes são bastante numerosas e, a maioria dos membros possuem baixos níveis de escolaridade - muitos cursaram até o ensino fundamental e há alguns relatos de avós ou pais analfabetos.

(Anexo A)

\section{Instrumentos e Procedimentos}

Os dados da pesquisa foram obtidos através da utilização de dois instrumentos: genoprofissiograma e entrevista com roteiro semiestruturado. Foi desenvolvido, inicialmente, um genoprofissiograma com cada participante para identificar as configurações familiares, a escolaridade e as profissões dos membros de cada família.

O genoprofissiograma é a construção de uma árvore genealógica com uma ênfase particular sobre as profissões das três últimas gerações. Trabalha-se principalmente a dimensão vertical (pais, avós e bisavós) e a dimensão horizontal (irmãos, primos e tios). Por meio desse instrumento, procura-se investigar a genealogia das profissões familiares a fim de conhecer sua influência sobre a escolha do jovem e encontrar um sentido para a profissão escolhida (SOARESLUCCHIARI, 1997). Entre os dados trabalhados nesse instrumento estão, além das profissões que os membros exercem, aquelas que gostariam de exercer, suas 
características pessoais, idade, casamentos e separações (FILOMENO, 2005). Durante a produção do genoprofissiograma podem ser revelados elementos importantes no nível das estruturas e dinâmicas das famílias como as repetições de situações ou de acontecimentos que não teriam aparecido no discurso do entrevistado espontaneamente. As correspondências entre o discurso e o genoprofissiograma, podem ser muito reveladoras da dinâmica familiar (SOARES-LUCCHIARI, 1997).

As entrevistas foram realizadas pela pesquisadora, que atua como psicóloga no PSICOM (Serviço Comunitário de Orientação Psicológica da PUCRio), na sua sala de atendimento. A entrevista foi realizada com base em roteiro semiestruturado (Anexo B), gravada e transcrita em sua íntegra. Foram abordados os seguintes temas: motivações para ingressar no Ensino Superior; expectativas quanto aos resultados acadêmicos durante a graduação; expectativas com relação ao mercado de trabalho depois da formatura; histórico familiar de formação educacional; histórico pessoal de formação educacional; valores familiares; conhecimentos sobre programas de inserção social. O PSICOM (Serviço Comunitário de Orientação Psicológica da PUC-Rio) conta com duas psicólogas. Os sujeitos selecionados para participar da pesquisa eram acompanhados pela outra psicóloga do Serviço.

\section{Cuidados Éticos}

A participação dos sujeitos foi voluntária, sem apresentar prejuízos ou se configurar como condição para continuação dos atendimentos no PSICOM (Serviço Comunitário de Orientação Psicológica da PUC-Rio). O projeto foi avaliado e aprovado pelo Comitê de Ética da universidade onde foi desenvolvido e todos os participantes assinaram o Termo de Consentimento Livre e Esclarecido (Anexo C), no qual foram explicitados os objetivos da pesquisa, os procedimentos e os cuidados éticos referentes à confidencialidade dos dados dos sujeitos. Os nomes dos participantes, e daqueles que foram citados por eles, foram substituídos por nomes fictícios.

\section{Análise dos dados}

O material transcrito foi submetido ao método de análise de conteúdo (BARDIN, 2011). A partir do discurso dos entrevistados emergiram sete 
categorias de análise: educação como valor familiar; influências no projeto educacional; o diploma da família; percepção dos jovens sobre programas sociais; obstáculos e desafios durante a graduação; rede de apoio como suporte e ampliação dos horizontes. Tendo em vista os objetivos deste trabalho, apresentaremos e discutiremos as três primeiras categorias.

\section{2}

\section{Resultados e discussão}

\section{Educação como valor familiar}

A educação como um valor familiar apareceu no discurso de todos os participantes e foi enfatizada como um bem ou uma herança transmitida a eles desde pequenos. As falas dos sujeitos apontam atitudes dos pais que revelam a importância dos estudos e o empenho deles em manter os filhos envolvidos em atividades educativas, desde a infância. A baixa escolaridade dos pais não foi obstáculo para a transmissão do valor da educação. Essa característica parece ter contribuído para um investimento maior no acompanhamento das tarefas escolares dos filhos e para a valorização da educação formal.

A minha mãe sempre incentivou a gente a estudar, sempre, sempre. Ela sempre disse que: "Ah, herança de filho de pobre é estudo". E ela sempre incentivou, colocava a gente em cursinho. Eu ficava pendurada na escola direto em matemática, botava em explicador. Sempre botou a gente, tentou botar a gente em curso e essas coisas (Luciana).

Meus pais sempre tinham, sabe como é que é, obrigaram a gente a estudar, sabe? Meu pai, quando eu era pequeno, ia na escola comigo, exigia dever de casa, se não colocasse presença na minha carteirinha ele ia lá e: "ah, porque? tem que colocar presença”. (Rafael)

$\mathrm{O}$ valor do estudo vem desde bem pequenininha mesmo. Eu entrei na escola bem novinha, acho que eu tinha 1 ano e meio, entrei no jardim 1 . Em casa, meus pais já ficavam ensinando o que era maior, o que era menor, as letras, sabe? E eu era muito pequenininha. Então eu sempre tenho essa imagem de todo mundo sentado, e quando tinha dúvida, todo mundo dando um jeito pra ajudar. (Gisele)

Os valores familiares são aspectos da vida individual e coletiva transmitidos, implícita ou explicitamente, pelos componentes do sistema familiar. De forma geral, os valores familiares perpassam temas que historicamente tem 
sido considerados como relevantes para as famílias ou que vem sendo incorporados devido aos avanços sociais. Mantem-se, por um lado, a tradição do casamento, por outro lado, ampliam-se as exigências relacionadas ao estudo, devido à maior competitividade profissional (FALCKE \& WAGNER, 2005). Através da educação, os pais vão atribuindo significado às experiências dos filhos, possibilitando ou dificultando conquistas, incentivando ou remediando sonhos (WAGNER, PREDEBOM \& FALCKE, 2005).

Nas falas dos participantes, podemos identificar também outros valores associados à educação passados pela família como a honestidade, o mérito, o investimento em algo produtivo, além de um senso estratégico - estudar e trabalhar para alcançar objetivos.

Meu pai sempre foi, tipo, ele tentou passar pra mim que tinha que ser honesta, que tinha que conseguir as coisas trabalhando, estudando. Ele sempre falava pra ser alguém na vida, pra arranjar um trabalho melhor, eu tinha que estudar. (Nathalia)

Eu vejo meus pais e preciso realmente ajudar minha família. Não nasci em berço de ouro, sabe? Não sou nenhum herdeiro, como muita galera que eu vejo aqui na universidade, então, de uma forma ou de outra, eu preciso desse diploma, sabe? Acho que é por isso que eu ainda não desisti. (Rafael)

Nem sempre os participantes parecem ter consciência da transmissão desses valores por parte dos pais, mas pode-se ver nas falas dos sujeitos a importância dada aos estudos para o seu desempenho no futuro.

Olha... da parte das minhas irmãs, eu acho que elas tem noção da importância, ne? A Mariana de ter se formado em turismo e a Paula pelas filhas dela, né? Por estarem fazendo também o ensino superior. Elas sabem que pra você conseguir alguma coisa hoje em dia, ter uma vida melhor, é a partir da educação. (Luiza)

Eu acho assim, que pra você planejar um futuro ele (o estudo) tá em primeiro lugar. Se você: "ah eu tenho um, eu penso que daqui, sei lá, cinco anos eu já quero ter uma casa", começa a estudar desde já. Estudar pra conseguir um emprego que te dá uma remuneração melhor pra você poder conquistar as coisas que você quer. (Luciana)

Como assinala Soares (2002), as redes de relações familiares, incluindo avós, bisavós, tios e primos, estão sempre presentes, de uma forma ou de outra, nas escolhas profissionais. E o jovem recebe essa influência no momento de uma 
escolha profissional, mesmo que muitas vezes sem ter conhecimento dessas influências recebidas no meio familiar. $\mathrm{O}$ jovem busca escolher um futuro que esteja relacionado, de algum modo, com os valores da família, e acaba considerando essas influencias recebidas no momento de uma escolha, quer elas sejam explicitas ou sutis (FILOMENO, 2005).

Alguns participantes reconhecem o valor da educação como um legado familiar transmitido a partir das histórias e experiências de vida de seus pais. Nem sempre, no entanto, o valor da educação foi exaltado nas gerações anteriores das famílias desses sujeitos, como evidenciado nas falas de Marcelo e Julia, cujos avós paternos não incentivaram os filhos a estudar. No entanto, os pais deles se empenharam em passar para seus próprios filhos a importância de uma educação formal. A forma como os pais dos entrevistados lidaram com esse valor em suas respectivas famílias de origem, portanto, o modo como esses pais absorveram e se apropriaram do valor da educação é que parece influenciar a forma como este valor foi passado para a geração seguinte.

Meus avós por parte de pai não incentivaram muito (a estudar), a vida dele pra estudar era muito sofrida, tinha que acordar muito cedo, pegar barca. Meu pai sempre falou que nunca ia me negar educação, realmente nunca negou, sempre pagou curso pra mim, e material nunca faltou pra mim. (Marcelo)

(sobre a importancia dada ao estudo) Acho que isso é muito dele (pai), tanto que a família dele não tem muita escolaridade. Acho que isso é muito mais do meu pai do que dos pais dele. Diferente de mim, que tenho isso porque eles passaram pra mim. (...) Acho que também tem uma coisa que é minha, porque eu tenho vontade de ser alguém, de fazer alguma coisa, porque mesmo eles me passando isso, eu poderia não querer. (Julia)

Quanto ao valor da educação transmitido, há falas que apontam que, nas gerações anteriores, algumas vezes, embora estimulados a investir na escolarização, alguns dos pais dos participantes não sustentaram a continuação dos estudos, mas insistiram em transmitir esse valor aos filhos.

(...) na verdade, minha mãe também sempre foi muito incentivada a estudar, mas ela preferiu se casar que achou que ia ganhar liberdade e tal. Foi bem assim. E meu avô briga com ela até hoje por causa disso. "Ah, viu? Se você tivesse estudado a gente estaria melhor". Meu vô falava: "eu posso pagar. Ou eu pago seu casamento, ou eu pago sua faculdade, te ajudo a pagar sua faculdade". Aí minha mãe preferiu o casamento. Aí por causa disso também, minha mãe sempre ficou muito em cima de mim. "Não! Você tem que... você não vai casar cedo, vai fazer faculdade antes". (Nathalia) 
Meu pai não pôde terminar a faculdade que ele queria fazer, minha mãe nem teve oportunidade de tentar uma faculdade. Eu podia escolher ter sido só técnica em mecânica e continuar, podia ter escolhido fazer outros técnicos, mas eu escolhi a faculdade, é uma etapa da minha vida acadêmica e tem esse lado muito afetivo da faculdade que é a minha família toda envolvida. (Gisele)

De acordo com Ramos e Oliveira (2008), a família é a transmissora de valores e regras sociais, mas ela o fará de acordo com a vivencia e percepção de cada um de seus membros. Pode-se pensar, nesse caso, que as vivências dos pais dos sujeitos os tenham levado à reflexão e à transmissão de forma mais apropriada desse valor da educação.

\section{Influências no projeto educacional}

O projeto educacional dos jovens entrevistados parece ser perpassado por diversas influências sociais e familiares, apontando para uma construção conjunta e não somente individual. Alguns não sabem definir exatamente o porquê de estarem cursando o ensino superior como uma etapa desse projeto educacional. Para eles, essa escolha parece ser algo naturalizado ou incorporado como um destino inquestionável. Contudo, em suas falas, apontam influências do ambiente social no qual foram criados.

Na verdade, eu sempre fui incentivada, como se fosse uma obrigação. Você tem que ir para a faculdade, porque assim, tipo, a vitória era ir pra faculdade (...). Na verdade, acho que é uma coisa muito natural, assim. Meio que eu não parava pra pensar se eu ia fazer ou não, eu tinha certeza que eu ia fazer faculdade em algum momento da minha vida. (Nathalia)

A escolha de vir para faculdade, eu não tive muita, era quase como dado que eu faria faculdade. Ate quando eu não sabia o que era uma faculdade, como era a faculdade. (...) era uma coisa dada, eu via filmes, terminou a escola, tem que passar pra faculdade (Marcelo)

Então, e minha madrinha, ela é professora de português, e meu padrinho, ele é médico e a família toda deles é de médico, seria meus tios (patrões da mãe, padrinhos considerados como tios), meus irmãos, sei lá, enfim... Então, eu sempre fui criada nesse ambiente de estudo, entendeu? (Antonia)

O projeto, portanto, não é puramente individual, uma vez que ele é formado no seio da família e da sociedade (ALMEIDA \& MAGALHAES, 2011; FERNANDES \& GONÇALVES, 2012). De acordo com Wagner et al (2012), é importante ainda analisar as estratégias utilizadas pelos progenitores para passar 
normas e valores, uma vez que essas irão influenciar o comportamento dos filhos. Essas estratégias, também conhecidas como estratégias de socialização, referemse a um conjunto de condutas cujo objetivo é moldar, através da intervenção educativa, o tipo de comportamento e atitude que os pais valorizam como apropriado e desejável para o desenvolvimento pessoal e para a integração social de seus filhos. Nas falas dos entrevistados, é possível identificar aquilo que é valorizado pelos pais, e o discurso que indica, de certa forma, o caminho a ser seguido, priorizando os estudos, conforme ilustrado nas falas a seguir:

Nossa! Meu irmão então... Eu já encontrava as pessoas na rua, as pessoas me davam parabéns. Eu: "gente, mas por que?". "Não, seu irmão me contou que você passou na universidade, parabéns!". Teve maior festa. Fizeram, a gente fez uma festa de comemoração. Foi a maior alegria. Minha mãe também, a mesma coisa: ligou logo pra família, falou pras amigas dela, nossa! (Luciana)

Ahh sempre, meu pai sempre foi... não rígido com isso, mas acho que eu foi uma coisa que eu criei também deles sabe? De estudar, de estudar primeiro e dar prioridade pro estudo e não trabalhar (...) é uma coisa que eles sempre falaram pra mim, acho que adquiri deles mesmo. (Julia)

De acordo com Ribeiro (2010), o projeto de vida do jovem é influenciado pelo projeto familiar e é parte integrante dele através de um processo contínuo de transmissão geracional, por meio de representações e ações sociolaborais compartilhadas. Através dessas interações, a família indica o que valoriza, quais são seus estereótipos, quais os significados atribuídos ao trabalho e quais são os caminhos de sucesso e insucesso que preconiza para seus filhos. A maioria dos participantes parece enxergar o estudo com uma das formas para alcançar o sucesso. No discurso dos entrevistados, as influências sociais e familiares parecem estar presentes como direcionadores, apontando para as possibilidades de escolha, como ilustram as falas a seguir:

A gente sempre foi criado falando da importância do estudo. Esses dias, a gente tava até lembrando que meu pai fazia assim comigo... com minha irmã também, mas ela não lembra. Ele pegava assim a foto "ahh olha aqui: tem 2 casas, ai uma era um barraco bem feio assim e uma casa bonita. Qual casa você quer ter?". Ai "ahh a gente quer ter a casa bonita, não o barraco, o sonho de consumo de ninguém é ter um barraco". Ai ele falava "Então ó, papai é pobre, mamãe é pobre, e para você ter essa casa bonita, você tem que estudar". Sempre foi assim, e ai, desde pequena, todo dia tem que tirar uma hora de estudo. Todo dia. Isso comigo e com minha irmã. (Gisele) 
(sobre a família extensa) De forma geral? Bom, não sei se eles consideram muito importante ter ensino superior. Acho que eles consideram ser importante ser bem sucedido. Infelizmente, pra maioria das família pobres, classe baixa, ser bem sucedido é ter um carro, ter uma casa e bom emprego, sabe? Não importa se você tem ensino superior ou não. Mas, pra mim, pra eu ter isso, eu tenho que ter ensino superior, sabe? Porque, tipo, não optei pela carreira militar, não sou jogador de futebol, também não sou sambista, nem funkeiro, então (risos)... Sobrou o estudo. (Rafael)

Segundo Andrade (1997), a relação entre os aspectos psicossociais familiares e a estruturação ocupacional do indivíduo é evidenciada de diversas formas. A própria identidade profissional e autoestima dos membros da família, fatores-chave para a escolha da carreira e para a administração da vida profissional, influenciam, muitas vezes indiretamente e não explicitamente, a ideologia familiar sobre os valores e conceitos ocupacionais. Grande parte dos entrevistados, quando falam sobre suas escolhas profissionais, se remetem às ocupações de seus pais. Uma parte dos entrevistados parece identificar, no caminho dos pais, escolhas que não devem ser repetidas. Outros sujeitos parecem enxergar em seus pais inspiração para criarem seus próprios projetos ocupacionais, e, possivelmente, superarem obstáculos, ultrapassando as conquistas dos pais.

Meu pai e minha mãe sempre me apoiaram em querer fazer design, o que não é muito comum ne? As pessoas... hoje em dia pode até ser mais né? O mercado de trabalho essas coisas, o que ele não gostava era que eu fizesse pedagogia, como ele é professor não queria que eu fosse professora também (...). Ele falava: você vê como eu sofro, você quer passar por isso também? (Julia)

Eu via meu pai fazendo as coisas, né? Ele construiu a minha casa e tal, eu achava aquilo muito bonito, do nada saía um edifício. E ele fez parte do shopping, foi fazer o shopping lá em Itaipú, o único shopping que tem em Itaipu. Então, eu fico assim, tipo... não tinha nada ali, Antonia, isso aqui era um deserto, e realmente era um deserto, não tinha nada, e agora ta aquele monumento né? Posso dizer, então, é uma coisa absurda (...) e isso sempre me encantou. (Antonia)

Outra influência presente no discurso dos entrevistados é o sentimento de realização que seus pais relatam quanto aos seus próprios trabalhos.

Porque meu pai trabalha muito, ele fica extremamente cansado, mas assim... eu nunca vi meu pai se queixar do que ele faz. Às vezes, ele se queixa de como ele faz, porque são muitos lugares, ele fica cansado. Ele se queixa do percurso, mas ele é muito apaixonado pelo que ele faz como profissão. A minha mãe é outra. Ela reclama, reclama das contas, reclama que tem muita burocracia, 
de quem tem que anotar isso, de que tem que fazer aquilo, tem que ver prazo, tem que lidar com outras empresas, mas ela adora o que ela faz. (Gisele)

Eu sempre pensei no meu lado profissional em ser bem sucedida, não só no lado de currículo, dinheiro, mas ser feliz no que eu faço. (Gisele)

Os pais parecem assumir um papel importante no processo de decisão do futuro ocupacional de seus filhos. As conversas estabelecidas com os filhos sobre emprego e a satisfação relacionada ao mundo do trabalho, são considerados pelos jovens no estabelecimento de seus planos futuros (SOBROSA et al, 2015). É no convívio com a família que se formam os conceitos, aspectos extremamente importantes quando consideramos a estruturação de um projeto de carreira. Pais que, ao voltarem do trabalho, cotidianamente reclamam atenção familiar por se sentirem cansados e que se referem ao trabalho com desagrado, não podem esperar que os filhos se entusiasmem com suas incipientes carreiras, mesmo quando o discurso paterno - agora modificado e ambiguamente "motivador" aponte nesta direção. Por outro lado, quanto mais os filhos percebem a satisfação profissional dos pais, e principalmente da mãe, maiores são as possibilidades de também sentirem-se entusiasmados e esperançosos com a própria carreira e sentirem a influência familiar como bastante positiva (ANDRADE,1997; OLIVEIRA \& DIAS, 2013; STANK ET AL, 2014).

A influência familiar quanto à escolha profissional está relacionada, sobretudo, às expectativas dos pais. Essas expectativas podem aparecer de diferentes formas: na pressão para que o filho opte por determinada profissão, através de oferta de apoio, no incentivo a determinadas atividades ou simplesmente na expressão de uma opinião (ALMEIDA \& PINHO, 2008; OLIVEIRA \& DIAS, 2013). Os entrevistados parecem identificar, nos esforços de seus pais para oferecer suporte para o aprimoramento acadêmico, a expectativa de que eles tenham mais oportunidades de crescimento profissional do que seus pais tiveram.

Como eu fui criada no trabalho da minha mãe e com pessoas que tiveram acesso à educação e crescimento pessoal e essas coisas, eu sempre tive contato, né? Então, sempre me incentivaram a estudar, a buscar alguma coisa, sabe? Pra melhorar a minha vida e tal. E sempre me ajudaram com o curso, desde que eu era pequena. É sempre me ajudaram, então eu sempre tive isso de "ah. Vou continuar". A minha mãe incentivou também. Ela falou "olha, Luiza, tem que estudar. Pra num sei que. Pra fazer suas coisas. Ter uma vida melhor do que a minha e tal. Não to te criando pra você ser empregada.” Essas coisas. (Luiza) 
Apesar de haver grande influência familiar, em especial dos pais, nas escolhas envolvidas no projeto educacional, nem sempre ela é reconhecida explicitamente por esses jovens. $\mathrm{O}$ fato de os pais não estarem familiarizados com o ambiente acadêmico pode resultar em sentimento de distanciamento e desconhecimento das opções universitárias por parte dos filhos. A escolha pela universidade, sobretudo a escolha do curso, é percebida por alguns entrevistados como sendo realizada de forma totalmente autônoma e quase solitária.

A escolha do curso não, eu fiz sozinha mesmo. Agora, da faculdade, na verdade eu não sabia que a universidade $X Y Z$ existia antes de fazer a prova. Eu conheci a universidade XYZ no dia que eu vim fazer o vestibular e eu conheci através do curso, porque lá no pré-vestibular eles apresentam as universidades, aí chamam profissionais que se formaram na e tal, e fazem algumas visitas. (Luciana)

No ensino médio eu tinha muitas dúvidas, assim, tipo em relação a qual curso iria seguir, porque no ensino médio eu gostava muito da área de humanas e também gostava da área de exatas. (...). Aí saiu uma reportagem no caderno de tecnologia e saiu uma reportagem sobre a robótica, que é a equipe de robótica daqui, ai, gostaria muito de fazer parte dessa equipe. Aí tentei engenharia na universidade XYZ, né? (Rafael)

O jovem, inserido numa família com seu dinamismo próprio, escolhe uma profissão muitas vezes sem ter consciência das influências que recebe do meio familiar. No entanto, essas influências, que estão presentes em todas as escolhas de vida de cada um dos sujeitos se fará presente, principalmente, na escolha profissional (SOARES-LUCCHIARI, 1997; BARDAGI \& HUTZ， 2008; MATOS, 2015). Alguns sujeitos entrevistados reconhecem, ainda, outras pessoas, além da família, que influenciaram diretamente suas escolhas profissionais.

Aí, uma coisa que me fez escolher a engenharia civil foi que, na sexta série, eu tive uma professora de matemática fenomenal, e ela era engenheira, ela também tinha uma família muito muito humilde e ela conseguiu vencendo a vida do pouquinho que ela tinha né? Que a família dela é de Minas também, então ela subiu, subiu e conseguiu se formar em engenharia, fez matemática e hoje dá aula de matemática e ainda dá algumas coisinhas de engenharia com o marido que também é engenheiro. E foi uma frase que ela me disse que eu carrego comigo até hoje, é: "Podem tirar tudo de você, menos o seu estudo e aquilo de bom que você fez pelas pessoas.", então é com isso que eu vou levando a vida, sabe? (Antonia)

Foi aonde eu tive a sorte de cursar o restante do ensino médio. E a galera que eu encontrei lá era uma galera... porque assim, na baixada a galera não pensa 
muito, naquela época. Bom, agora essa visão também tá mudando, graças a Deus. Mas, antes a galera não pensava muito em terminar e fazer faculdade, pensava em entrar no mercado de trabalho, até porque você tem que ajudar em casa, essas coisas, essas questões complicadas. Mas aí, esse colégio que eu estudei, nessa turma, tinha uma galera que realmente pensava em seguir, sabe? E aí eu meio que surfei essa onde, sabe? E me dediquei, e tal, e fui trocando uma ideia com os professores. (Rafael)

Em pesquisa realizada com jovens provenientes de classes socioeconômicas desfavorecidas sobre as influencias percebidas na escolha profissional, Sobrosa et al (2015) apontam que, em relação ao curso superior, a maioria $(65,5 \%)$ dos entrevistados acreditava não ter sofrido influencias externas, $14 \%$ acreditavam terem sido influenciados por alguém e 20,5\% não responderam à questão. Os autores ressaltam que a dificuldade dos alunos em reconhecer a influência de terceiros no processo de decisão por uma profissão pode ser compreendida pela conotação negativa dada ao termo "influência" quando se trata de orientar o futuro dos jovens, pois "influência" poderia significar direcionar uma escolha profissional. Os estudantes que identificaram interferência de terceiros na escolha da profissão citaram familiares, amigos, mídia e professores como as principais fontes de influência. Esses resultados corroboram os encontrados em nossa pesquisa, e podem auxiliar no entendimento das razões que podem levar ao não reconhecimento explícito da influência dos pais nas escolhas de seus filhos.

\section{O diploma da família}

O diploma universitário parece ser uma conquista familiar para os jovens entrevistados. Eles reconhecem nos pais grandes incentivadores de sua trajetória e apreciadores orgulhosos de seu sucesso. É como se a entrada na universidade e, posteriormente, a conclusão de um curso de ensino superior, fossem conquistas coletivas e que respondem a expectativas familiares anteriores. Além disso, o diploma é considerado um retorno dado aos pais por todos os esforços empreendidos até que os filhos chegassem a um lugar privilegiado, do ponto de vista acadêmico.

Eles dão muito valor, sabe? Porque era uma coisa inalcançável, né? Ainda mais minha mãe, que saiu lá de uma cidade do interior de Minas, veio pra 
o Rio de Janeiro, pra trabalhar em casa de família, como que a filha dela ia estar? Minha mãe adora falar isso, está na melhor faculdade do Rio de Janeiro, então, como que ela conseguiu tudo isso, né? Como que eu consegui tudo isso? Então, muita gente dá muito valor. (Antonia)

$\mathrm{Na}$ minha família, comigo são três pessoas que cursaram o ensino superior. Na minha geração, eu sou a segunda. E eu acho que tem uma importância altíssima na minha vida e na vida da minha mãe também, por ela ter sempre incentivado essa coisa da educação, estuda, estuda, faz curso, pega as oportunidades que você tem. Eu acho que significou muito também pra ela, assim, em relação a dar, é como se eu tivesse dado um presente pra ela também. Eu me presenteei, mas eu presenteei ela também. (Luciana)

É como se toda família possuísse um grande livro simbólico no qual está contida a contabilidade das dívidas e dos méritos acumulados através das gerações. Trata-se do legado, da herança dos méritos referidos à expectativas estruturadas, diante das quais todas as pessoas na família assumem compromissos, influenciando, desta forma, suas escolhas ao longo da vida (BOSZORMENYINAGY \& SPARK, 1984; BUCHER-MALUSCHKE, 2008; KROM, 2000). Todos os entrevistados pontuaram a importância de estarem cursando o ensino superior para suas famílias e muitos deles colocaram a questão de estarem realizando algo que seus pais gostariam de ter realizado, mas que, por motivos diversos, não o fizeram. Os sonhos e desejos desses pais se transformam, então, em uma missão para os filhos.

A minha mãe tem bastante orgulho de mim por eu estar fazendo faculdade. Ela até me falou quando eu passei... todo dia eu ligo de manhã pra ela, a gente conversa... Ela falava: "nossa Marcelo to tão feliz que você ta na faculdade, porque é um sonho que eu nunca pude cumprir, nunca pude realizar". Então pra ela é bastante importante nesse sentido. (Marcelo)

E meu pai, ele não podia estudar, porque ele teve que trabalhar muito novo. Mas ele sempre quis estudar, ele sempre gostou muito de estudar. Então ele também me pressionava pra fazer uma faculdade. Meu avô materno, ele também sempre incentivou, ele também gosta muito de estudar. Ele também não teve oportunidade, então acho que por isso também que ele incentivava tanto minha mãe, acabou me incentivando muito. (Nathalia)

Todo ser humano tem uma missão familiar a cumprir, seja ela explicita ou implícita. As famílias tem suas próprias leis derivadas do padrão do sistema familiar herdado e desenvolvido pelos pais e filhos na família. Tal padrão cria uma rede de obrigações que é responsável pela construção de um sistema de contabilidade. Assim, cada membro da família acha-se subordinado às expectativas que vai cumprir, ampliar ou, de algum modo, reagir a elas 
(BORNHOLDT \& WAGNER, 2005; FILOMENO, 2005; SANTOS \& CERVENY, 2013). Muitas vezes, os pais podem investir os filhos da missão de realizar os sonhos que eles mesmos não puderam realizar (SOARESLUCCHIARI, 1997; BUCHER-MALUSCHKE, 2008).

Alguns membros das famílias dos participantes desta pesquisa possuíam ensino superior completo, outros deram início a uma faculdade, mas não finalizaram ou não puderam escolher o curso que gostariam de cursar. Questões socioeconômicas parecem ter influenciado essas decisões. Os entrevistados apontam a falta de oportunidades como uma das razões para o abandono desses projetos por parte de seus antepassados. Nesses casos, como ressalta Reis (2013), o amplo acesso a informações através de diversos meios de comunicação e o desenvolvimento sociocultural em que a sociedade brasileira se encontra hoje podem ter permitido às gerações mais jovens dispor de recursos que possibilitaram lidar com as situações de maneira diferente de como lidaram seus antepassados.

Eu vejo a minha realidade com a realidade da minha mãe, na época dela, ela não tinha essas coisas, então ela realmente não tinha oportunidade. Agora, eu acho que com esses projetos, a minha geração já foi beneficiada, as futuras também vão ser, espero que continuem. (Luciana)

A família do meu pai, os meus tios que dão mais valor à faculdade, que não são todos, eles não tiveram oportunidade de escolher fazer uma faculdade, de escolher fazer um vestibular, por circunstancias da vida. Então, eu passar no vestibular, para eles era: "Uaaaau! Gisele passou no vestibular". E para minha tia, eu lembro até hoje quando eu falei que passei no vestibular essa minha tia chorando porque ia ser outra mulher a fazer uma faculdade na família e porque eu escolhi o curso. Ela não é feliz em pedagogia, ela fez pedagogia porque era o mais barato, porque era o que mulher conseguiria fazer na época dela. E ela vê que eu escolhi fazer um curso, um curso que teoricamente é masculinizado né? Que é engenharia, e ela ficou muito emocionada com isso. (Gisele)

Com a abertura das oportunidades de acesso à educação superior, ampliase a possibilidade de escolha desses jovens por uma carreira, através da ampliação de oferta de cursos de graduação. No momento dessa escolha profissional, a qualidade da vinculação pais-filhos pode favorecer uma escolha realística e autônoma, ou limitá-la, contribuindo para a indecisão profissional ou assunção de projetos outorgados por outros. Famílias estruturadas - menos rígidas e flexíveis que fomentam o investimento vocacional sem imposição de metas incompatíveis com os recursos dos filhos, são favorecedoras da exploração vocacional, 
facilitando o processo de escolha. A relação de proximidade entre pais e filhos, incluindo apoio e ações dos pais em direção à exploração vocacional dos adolescentes, tem influência direta na exploração mais intensa por parte dos filhos no período de escolha e na maior autonomia para a escolha (ALMEIDA \& MELO-SILVA, 2011).

No discurso dos participantes, o olhar dos pais para as habilidades e interesses dos filhos foi destacado como grande influência para a escolha profissional. Pôde-se observar ainda que aqueles que relatam ter tido um olhar parental acolhedor com relação às suas individualidades sentem-se mais alinhados com o destino escolhido.

$\mathrm{Na}$ escola, antes da sexta série eu era mais largadinha, meus pais tinham que ficar em cima. Depois fui indo sozinha. Eles acompanhavam, eles não me batiam se eu tirasse nota baixa. Eles perguntavam. Eu sempre fui aluna mediana. Hoje na faculdade, penso diferente. Não eram pais rígidos com isso, que me fizessem ter medo. Sabiam das minhas dificuldades e respeitavam elas. (Julia)

Diz minha mãe que quando eu era criança, eu não pegava panelinha pra fazer comida, eu fazia massa, então... (risos) engelharia civil ja ta aí, fazia tijolinho e tal... (Antonia)

Os pais influenciam fortemente as escolhas dos filhos, e as escolhas dos filhos também fazem os pais repensarem sobre as suas próprias escolhas (FILOMENO, 2005). Como apontado por KROM (2000), em muitos períodos da vida as expectativas parecem estar adormecidas, mas, tão $\log$ o são tocadas em alguns pontos sensíveis, mostram-se revigoradas. Nas falas dos participantes observou-se que, ao acompanharem a trajetória acadêmica dos filhos, os pais reveem seu próprio histórico acadêmico, relatam essa história para os filhos e repensam suas possibilidades de retomar esse caminho. Muitos desses pais abandonaram os estudos em etapas iniciais do ensino formal e ainda nutrem o desejo pelo aprendizado.

Minha mãe pensa em voltar a estudar. Só que ela tá esperando meu irmão ficar maior pra ela conseguir algum trabalho fixo, e poder tentar alguma faculdade. (Nathalia)

A minha mãe tinha vontade de estudar, mas eu nasci. Ela deu prioridade pra isso. Ela ainda pensa em dar aula, mesmo estando com 53 anos. (Julia) 
(...) ela (mãe) sempre pensou em voltar a estudar mas aí o Mariano nasceu, aí agora ela tá pensando em voltar a estudar de novo, mas ela não tem tempo, porque ela trabalha de domingo a domingo (Antonia)

Os participantes percebem que, na medida em que os pais veem, através dos filhos, que é possível atingir aquele objetivo do estudo, interrompido há tempos atrás, seja pela falta de oportunidades, seja pela prioridade que precisou ser dada a outras áreas da vida, a vontade de retomar as atividades acadêmicas parece ser despertada e começa a ser repensada.

\section{3}

\section{Considerações finais}

No Brasil, com a ampliação das políticas sociais de acesso à educação, nos últimos anos, um número cada vez maior de jovens com perfil socioeconômico filantrópico tem ingressado nas universidades. O estudo, para esses jovens, tem sido visto como uma forma de conquistar melhores oportunidades de emprego e como um caminho possível e desejável para maiores conquistas sociais e econômicas.

O projeto de cursar o ensino superior, apesar de ser uma escolha individual, é desenhado e desenvolvido de forma coletiva, em conexão direta com as influências recebidas do grupo familiar e do contexto sócio-histórico dos sujeitos. No discurso dos jovens entrevistados, o estudo aparece como um valor transmitido desde a infância, mesmo quando os próprios pais não conseguiram alcançar altos níveis de formação acadêmica. O jovem de perfil socioeconômico filantrópico que ingressa no ensino superior, muitas vezes, é o primeiro ou um dos primeiros de sua família a alcançar tal conquista.

Os jovens entrevistados, ao seguirem sua trajetória acadêmica na universidade, parecem estar buscando honrar o que receberam de seus pais e antepassados, zelando pela herança dos valores transmitidos e podendo realizar modificações na vida de seus familiares e das comunidades em que vivem. $\mathrm{O}$ ingresso no ambiente universitário parece mostrar que é possível trilhar caminhos de transformação, contribuindo para alterações positivas da realidade das famílias 
de perfil socioeconômico filantrópico, trazendo grande satisfação para os pais e familiares que forneceram suporte para essas conquistas.

3.

\section{Transformando oportunidades em conquistas: questões sobre a trajetória acadêmica de universitários bolsistas}

\section{Resumo}

Realizamos ampla pesquisa com o objetivo de investigar a percepção do jovem universitário de perfil filantrópico sobre o papel da família no seu projeto educacional. Foram entrevistados oito jovens universitários e as entrevistas foram analisadas pelo método de análise de conteúdo. Das narrativas emergiram sete categorias temáticas. Para apresentação e discussão neste trabalho, cujo objetivo específico é investigar a percepção dos sujeitos sobre as políticas sociais de inclusão para jovens com perfil filantrópico e pesquisar sobre suas experiências ao longo da graduação, destacamos as seguintes categorias: percepção dos jovens sobre programas sociais; obstáculos e desafios durante a graduação; rede de apoio como suporte e ampliação dos horizontes. Os resultados apontam para uma avaliação favorável dos participantes a respeito de programas sociais de inserção, apesar de apontarem a necessidade da expansão dos mesmos para além das capitais brasileiras. Como principais dificuldades ao longo da trajetória acadêmica encontraram-se as questões das longas distâncias entre a universidade e o local de residência, da transição do ensino médio para o superior e e os custos de manutenção e permanência na universidade. No enfrentamento das dificuldades, os sujeitos contam com suas redes de apoio que incluem os pais, os amigos e o apoio institucional. Essa experiência de cursar o ensino superior parece trazer ainda, alguns outros significados como a abertura de horizontes, o retorno para a família e o lugar de exemplo.

Palavras-chave: Programas sociais; dificuldades; rede de apoio; universitários; perfil socioeconômico filantrópico. 


\begin{abstract}
We carried out a wide research aiming to investigate the perception of young university students with philanthropic profile regarding the role of family in their educational project. Eigh university students were interviewed, and the results were assessed according to the content analysis method. Seven theme categories emerged from the subjects' narratives. The purpose of this work is to investigate the perception of these subjects regarding the inclusion social policies for philanthropic profile students as well as to research into their experiences throughout the undergraduate course. Therefore, in order to present and discuss these matters, we highlight the following categories: the students' perception of social programs; obstacles and challenges during graduation; support network to expanding horizons. The results point out to a positive evaluation by the students regarding inclusion social programs, despite the fact that they underlined the need to expanding the access to such programs beyond Brazilian capitals. Among the main difficulties faced throughout their academic path are the long comutes, the transition from high school to university and the financial permanence of these scholarship students. Considering the facing of such difficulties, the subjects can count on support networks which include their parents, friends and also institutional support. Taking an undergraduate course seems to bring important meanings to their lives, like the opening of new horizons, the possibility of rewarding their families and becoming a role model to their communities.
\end{abstract}

Keywords: social programs; difficulties; support network; university student; philanthropic socioeconomic profile.

O princípio da equidade determina o imperativo ético de diminuir ao máximo as desigualdades sociais. Esse princípio se insere na esfera dos direitos públicos e sociais e diz respeito ao desenvolvimento do processo de construção da autonomia pessoal, da cidadania, da profissionalização e, por extensão, da sociedade democrática (SOBRINHO, 2013). As desigualdades sociais presentes no Brasil trazem para pauta a discussão sobre formas de diminuição dos abismos 
socioeconômicos e culturais que se instalaram ao longo dos anos na nossa sociedade.

Em resposta ao desafio de buscar uma sociedade mais justa e igualitária, surgem diversos movimentos sociais, com novas propostas de ações. Com uma proposta baseada no reconhecimento e respeito às diferenças, ações afirmativas voltadas para a garantia e ampliação dos direitos sociais de determinados grupos reconhecidamente em condições de desigualdade social começam a se estruturar (SALVADOR, HERINGER \& OLIVEIRA, 2014).

Segundo Salvador (2009), os novos movimentos sociais, durante as décadas de 1980 e 1990, trouxeram para o cenário político brasileiro novos atores, antigas demandas e questões inéditas, que alteraram especialmente a dinâmica política do país. Nesse novo contexto, começaram a se organizar grupos sociais com identidades definidas - por raça, sexo, etnia, entre outros -, que exigiam seus direitos culturais e coletivos. Era uma nova forma de pensar direito e cidadania. A luta contra a condição de exclusão e carência se mantinha, e o que passou a ser distinto foi a maneira como essa carência passou a ser vista: como um direito. Nesse contexto, surgem as primeiras políticas afirmativas nas universidades públicas e privadas, abrindo o debate acerca da necessidade de expansão do ensino superior.

O debate sobre ação afirmativa no Brasil é relativamente recente, e a área em que houve maior avanço destas políticas foi o campo do acesso à educação superior, com um diversificado leque de experiências institucionais que demonstram o vigor destas políticas, bem como os desafios a serem enfrentados na implementação das mesmas (SALVADOR, HERINGER \& OLIVEIRA, 2014).

Como destacado por Assis, Sanabio, Magaldi e Machado (2013), a expansão das universidades brasileiras, ao longo dos anos, fez com que a oferta de vagas aumentasse substancialmente no ensino superior. A expansão do número de vagas e o aumento das oportunidades de ingresso no nível superior, principalmente em razão das políticas de acesso e inclusão social em curso, nos últimos anos, tornou a questão da permanência dos estudantes nas universidades um tema de grande relevância. A democratização do acesso contribuiu para que alunos com condições socioeconômicas desfavoráveis e distintas trajetórias educacionais fossem incorporados a este nível de ensino. 
A transição do ensino médio para a universidade é marcada por desafios complexos para o jovem acadêmico. Alguns estudantes logram caminhos construtivos nesta transição e se integram na vida universitária, enquanto outros se sentem sobrecarregados e conflitados ao enfrentar a demanda decorrente de seus novos papéis. O conceito de integração acadêmica envolve mais do que o simples desempenho aferido sob a forma de notas (ZORZO, SILVA \& POLENZ ,2002).

De acordo com Zorzo, Silva e Polenz (2002), a motivação humana depende da capacidade que o sujeito tem de reconhecer o significado do esforço a ser feito para lograr a concretização dos seus projetos de vida. Isso vale para toda a atividade humana, com peso adicional no desempenho acadêmico. Sem a percepção da correlação entre o esforço a ser feito e a consecução de um objetivo, o comportamento e a atividade em geral se tornam vazias de significado, perdendo sua força e efetividade.

Uma efetiva democratização do ensino superior requer políticas abrangentes de ampliação do acesso e fortalecimento do ensino, envolvendo programas voltados para permanência dos alunos no sistema universitário de ensino, sobretudo, aqueles que são provenientes de camadas socioeconômicas mais baixas/desprivilegiadas (ASSIS et al., 2013). É preciso estabelecer uma ligação entre as atividades de ensino, pesquisa, extensão e apoio ao estudante, visando a contribuir para que haja melhor desempenho acadêmico do aluno atendido, evitando também a repetência e a evasão. O presente estudo pretendeu investigar a percepção dos sujeitos sobre as políticas sociais de inclusão para jovens com perfil socioeconômico filantrópico e suas experiências ao longo do curso de graduação.

\section{1}

\section{Método}

\section{Participantes}

Participaram desse estudo 8 alunos universitários, de graduação, com perfil socioeconômico filantrópico, com idades entre 18 e 28 anos, que estão ou estiveram em atendimento no PSICOM (Serviço Comunitário de Orientação 
Psicológica da PUC-Rio) e que tenham relatado anteriormente a importância da sua família em sua vida acadêmica.

As famílias dos participantes apresentaram algumas características similares, como por exemplo, a migração. Dos oito participantes, apenas um tem família de origem do estado do Rio de Janeiro. Todos as outras famílias vieram de estados brasileiros diversos, muitos dos pais em busca de trabalho e alguns de melhores condições de estudo para si. Além disso, as famílias de origem dos participantes são bastante numerosas e, a maioria dos membros possuem baixos níveis de escolaridade - muitos cursaram até o ensino fundamental e há alguns relatos de avós ou pais analfabetos.

(Anexo A)

\section{Instrumentos e Procedimentos}

Os dados da pesquisa foram obtidos através da utilização de dois instrumentos: genoprofissiograma e entrevista com roteiro semiestruturado. Foi desenvolvido, inicialmente, um genoprofissiograma com cada participante para identificar as configurações familiares, a escolaridade e as profissões dos membros de cada família.

O genoprofissiograma é a construção de uma árvore genealógica com uma ênfase particular sobre as profissões das três últimas gerações. Trabalha-se principalmente a dimensão vertical (pais, avós e bisavós) e a dimensão horizontal (irmãos, primos e tios). Por meio desse instrumento, procura-se investigar a genealogia das profissões familiares a fim de conhecer sua influência sobre a escolha do jovem e encontrar um sentido para a profissão escolhida (SOARESLUCCHIARI, 1997). Entre os dados trabalhados nesse instrumento estão, além das profissões que os membros exercem, aquelas que gostariam de exercer, suas características pessoais, idade, casamentos e separações (FILOMENO, 2005). Durante a produção do genoprofissiograma podem ser revelados elementos importantes no nível das estruturas e dinâmicas das famílias como as repetições de situações ou de acontecimentos que não teriam aparecido no discurso do entrevistado espontaneamente. As correspondências entre o discurso e o genoprofissiograma, podem ser muito reveladoras da dinâmica familiar (SOARES-LUCCHIARI, 1997). 
As entrevistas foram realizadas pela pesquisadora, que atua como psicóloga no PSICOM (Serviço Comunitário de Orientação Psicológica da PUCRio), na sua sala de atendimento. A entrevista foi realizada com base em roteiro semiestruturado (Anexo B), gravada e transcrita em sua íntegra. Foram abordados os seguintes temas: motivações para ingressar no Ensino Superior; expectativas quanto aos resultados acadêmicos durante a graduação; expectativas com relação ao mercado de trabalho depois da formatura; histórico familiar de formação educacional; histórico pessoal de formação educacional; valores familiares; conhecimentos sobre programas de inserção social. O PSICOM (Serviço Comunitário de Orientação Psicológica da PUC-Rio) conta com duas psicólogas. Os sujeitos selecionados para participar da pesquisa eram acompanhados pela outra psicóloga do Serviço.

\section{Cuidados Éticos}

A participação dos sujeitos foi voluntária, sem apresentar prejuízos ou se configurar como condição para continuação dos atendimentos no PSICOM (Serviço Comunitário de Orientação Psicológica da PUC-Rio). O projeto foi avaliado e aprovado pelo Comitê de Ética da universidade e todos os participantes assinaram o Termo de Consentimento Livre e Esclarecido, no qual foram explicitados os objetivos da pesquisa, os procedimentos e os cuidados éticos referentes à confidencialidade dos dados dos sujeitos. Os nomes utilizados, dos participantes e daqueles que foram citados por eles, foram substituídos por nomes fictícios.

\section{Análise dos dados}

O material transcrito foi submetido ao método de análise de conteúdo (BARDIN, 2011). A partir do discurso dos entrevistados emergiram sete categorias de análise: educação como valor familiar; influências no projeto educacional; o diploma da família; percepção dos jovens sobre programas sociais; obstáculos e desafios durante a graduação; rede de apoio como suporte e ampliação dos horizontes. Neste trabalho, apresentaremos e discutiremos as seguintes categorias: percepção dos jovens sobre programas sociais; obstáculos e desafios durante a graduação; rede de apoio como suporte e ampliação dos horizontes. 


\section{2}

\section{Resultados e discussão}

\section{Percepção dos jovens sobre os Programas Sociais}

A principal contribuição dos programas sociais, na visão dos entrevistados, parece ser a de dar oportunidades de estudo àqueles que, por condições socioculturais não tiveram acesso a um ensino básico de qualidade. Esses programas, de acordo com as falas dos jovens entrevistados, parecem aumentar as possibilidades de desenvolvimento acadêmico de crianças e jovens com perfil socioeconômico filantrópico. Esses programas sociais fornecem meios para que esses sujeitos possam se manter investidos no caminho da educação, e que esse investimento possa vir a lhes gerar a possibilidade de alcançar maiores conquistas no futuro.

Muitas vezes, não tem o retorno que o pessoal concebe que é o financeiro. Então, ter todo esse amparo, toda essa..., mostrar que isso tem um valor, que é importante, acho que é isso que todos os projetos, as vias sociais para inserir as pessoas na educação fazem. Não importa qual seja o jeito, seja através de uma bolsa, seja através do acolhimento da família, todos eles estão inserindo a pessoa nessa opção de entrar, de se aprofundar numa vida acadêmica. E eu acho isso. (Gisele)

A minha sobrinha também, a Raíssa, ela tinha... nossa, não lembro o nome do programa que ela tinha. Mas ela tinha bolsa pra estudar naquele colégio super caro, o XYZ. Ela tinha bolsa lá. Então assim, ela também participou disso. Então o que ela é hoje, com certeza, é da educação que ela teve la atrás, né? E a importância desses programas é nesse sentindo de... de crescimento. (Luiza)

A visão dos entrevistados corrobora com os resultados de pesquisas realizadas com jovens formados, que foram beneficiários de uma bolsa de estudos em universidades brasileiras através de programas sociais. Em pesquisa realizada por Felicetti (2014), os resultados apontaram 91,8\% dos egressos trabalhando após menos de cinco anos de formados, 3,73\% desempregados e 4,47\% fora do mercado de trabalho por terem dado continuidade aos estudos no meio acadêmico. Dentre aqueles que estavam empregados, 65,85\% dos respondentes atuavam em sua área de formação, e a maioria, ou seja, 72,39\%, considerava-se satisfeita com seu trabalho atual. Amaral e Oliveira (2011), em suas pesquisas com ex-bolsistas afirmam que quase a totalidade deles está empregada e percebeu a formação 
superior que cursaram como geradora de ampliação das oportunidades de empregabilidade e melhoria na qualidade e vida e renda. Para os jovens ainda em formação em curso superior e bolsistas entrevistados por Saraiva e Nunes (2011), o nível de desemprego diminuiu ou, para os que ainda não trabalhavam, oportunidades surgiram por eles estarem no ensino superior.

A formação superior, além de instrumentalizar academicamente esses jovens, é percebida por eles como parte importante no seu desenvolvimento como pessoa. As vivências ao longo de sua formação, ajudam na promoção de um conjunto mais amplo de qualidades pessoais que os tornam melhor preparados para o mercado de trabalho, e consequentemente, mais propícios a terem melhores empregos e serem bem sucedidos profissionalmente (FELICETTI, CABRERA \& COSTA-MOROSINI, 2014). Mongim (2015) aponta que muitos desses estudantes veem a formação superior como uma forma de crescimento, como a autorização necessária para se apresentarem como sujeitos dotado de conhecimentos específicos capazes de tornar possível uma mudança da posição de trabalhador subordinado (trabalhando em funções não especializadas e que exigem formações abaixo do nível superior) para a de trabalhador especializado e com mais autonomia. Fazer um curso superior, portanto, permite deslocar-se para uma posição social supostamente de maior prestígio, e constitui, para estes estudantes, a grande recompensa.

Os jovens entrevistados enxergam nos programas de inserção social uma forma de inclusão e uma possibilidade de diminuir a desigualdade social presente na sociedade brasileira. A avaliação feita pelos sujeitos sobre esses programas é positiva, abrindo possibilidades de mudanças efetivas na vida daqueles que são beneficiados. É pontuado ainda que os benefícios que esses programas podem trazer dependem da forma com que cada pessoa vai usufruir deles, podendo levar à acomodação ou ser um propulsor de mudança de vida.

Acho que eles ajudam, são necessários. Não acho que é uma forma de segregar, mas de unir as pessoas que tem muitas dificuldades com outras que tem outros tipos de dificuldade, ou menos dificuldade, mas também tem dificuldades. A pessoa que não tem muita renda não tem educação legal, as vezes alimentação também não. Quem tem dinheiro não passa por isso, ela acaba sendo privilegiada de alguma forma. (Julia)

Eu acredito que é o que queira incluir né, as pessoas. Inserção social né? Que tentam não, vamos dizer... Não igualdade né, porque nunca vai ter isso, mas diminuir um pouco essa diferença que existe muito, eu acho que é isso. (Antonia) 
Eu acho super válido, porque, eu acho que o Brasil deveria ser um estado tipo o Farry state, sabe? Um estado de bem estar social. Então eu acho totalmente válido qualquer tipo de ajuda que o governo possa providenciar, sabe? Tipo. Tudo bem, tem a galera que se acomoda? Tem, mas tipo, se você olhar pro outro lado, tipo, tem muito mais gente que, tipo, consegue mudar de vida através daquilo. (Rafael)

Os jovens entrevistados acreditam que, uma vez que esses programas trazem muitos benefícios para quem tem acesso a eles, a divulgação deveria ser ampliada e chegar ao interior dos estados brasileiros. Uma vez que eles tiveram acesso a essas oportunidades, reconhecem o valor desses programas sociais em suas próprias trajetórias e desejam multiplicar as ações para que outras pessoas também possam ser beneficiadas. No discurso dos sujeitos, observa-se que, na percepção deles, o acesso parece ser mais facilitado para as pessoas que moram nas capitais do país.

Eu acho de grande importância deveria ser mais incentivado, eu acho que é uma coisa que fez muita diferença, faz muita diferença, né, tá dando oportunidade às pessoas, e ampliam o horizonte delas, tem gente que pensa assim, e a partir do momento que tem esses programas a mente se abre, então elas passam a ver o mundo de outra forma, e o que elas pensavam: "ah não, não da pra fazer isso", dá. Dá sim, e tem alguém pra te ajudar a chegar lá, sabe? Então eu acho que deveria ser melhor investido, e chegar em todos os lugares, não só nas capitais, que eu vejo que é muito nas capitais mesmo, então se pudesse ser ampliado, seria muito melhor e, como dizem né, a educação é a base de tudo, então esse programa acho que dá um suporte, pro futuro... (Antonia)

Então, eu acho assim, de extrema importância porque da chance de a pessoa ter uma escolha, uma opção que ela poderia não ter, que nem minha mae, por exemplo. Ela não poderia bancar uma faculdade, e o ensino que ela teve no Pará não dava bagagem para ela encarar um vestibular nos moldes que era antigamente. Entao, ela não tinha oportunidade mesmo de fazer faculdade. É... se ela fosse fazer faculdade, eu acho que ela ia ter que deixar de comer muitas vezes para se sustentar na faculdade, sabe? Entao eu acho que também da um auxilio para famílias que são mais de baixa renda, mais do interior também tem essa construção do valor do ensino, do valor do conhecimento, quanto mais conhecimento você tem, maior sua possibilidade de argumentar, melhor você compreende o outro também. (Gisele)

Outros tipos de programas sociais, que não se referem diretamente à educação formal, também são citados pelos sujeitos entrevistados como forma de ampliação de oportunidades e inserção social.

Eu acho que programa social, ele é pra dar oportunidade as pessoas de baixa renda, as mesmas oportunidades que as pessoas com renda maior tem. 
Então de inserir eles em, sei lá, atividades esportivas, que as vezes é difícil, né? Mas assim, não inserir assim em: vamos matricular, mas inserir em incentivar, ajudar a chegar até o local, essas coisas. (Luciana)

Eu já ouvi falar desse vale cultura. (...) acho que é, como se fosse um benefício das empresas. As empresas meio que, como se fosse um vale-refeição, mas destinado a programas culturais como teatro, peça, show, essas coisas. Talvez isso ajude a abrir um novo mundo pras pessoas. Tem gente que nunca foi ao teatro, que é bem caro, que nunca foi num show. Acho que traz uma riqueza cultural. Ou então viajar, sei lá, nem que seja pra alguma cidade histórica, alguma coisa assim. (Nathalia)

A inserção de uma política social no âmbito do ensino superior tem importante papel como forma de redução das desigualdades que se manifestam na sociedade, e por certo na instituição escolar, enquanto espaço de reprodução e produção de relações sociais (ASSIS et al., 2013). Em pesquisa com alunos universitários beneficiários de programa social que lhes permite o ingresso na faculdade como bolsistas integral, Saraiva e Nunes (2011), identificaram que esses jovens enxergam essa iniciativa como sendo efetiva na inclusão de minorias historicamente excluídas. Além disso, interpretam sua participação no programa como uma grande oportunidade e uma vitória, uma vez que associam limitações socioeconômicas a dificuldades de ingresso na educação superior por outras vias. A inclusão através da bolsa de estudos é associada, nesse sentido, a um sentimento de justiça. Nierotka (2016) endossa essa idéia apontando que a inclusão promove a justiça cognitiva, permite aos excluídos a apropriação dos saberes sistematizados, do conhecimento e da tecnologia historicamente construídos, que são essenciais no mundo do trabalho e no exercício da cidadania.

Casali e Mattos (2015) apontam que, nos últimos anos, houve expressivo avanço em relação às ações de ampliação quantitativa do sistema e diminuição das desigualdades regionais, bem como melhoria nos índices de equidade social e cultural no acesso à educação superior. No entanto, como pontuam Felicett, et al. (2014), as oportunidades abrem espaço para que esses sujeitos tenham as mesmas oportunidades de outros grupos de perfil socioeconômico mais favorável no tangente ao acesso ao ensino superior, mas o sucesso do programa depende do comprometimento de cada um, uma vez que, só aprende quem quer aprender, só aproveita as oportunidades quem quer deixar de ser o "diferente" para fazer a diferença na universidade e na sociedade. 


\section{Obstáculos e desafios durante a graduação}

As maiores dificuldades que os jovens de perfil socioeconômico filantrópico entrevistados enfrentam ou enfrentaram ao longo de sua trajetória acadêmica no ensino superior incluem: a transição do ensino médio para o ensino superior; a distância da universidade para seu local de residência; e os custos de manutenção e permanência na universidade.

A transição do ensino médio para o ensino superior foi citada pelos entrevistados, principalmente, nos seguintes aspectos: para alguns, o mais difícil era a forma de cobrança da faculdade que difere muito da escola; para outros, conciliar estágio - atividade própria dessa etapa do ensino - e estudo se tornou um grande desafio.

E foi um choque, porque na escola eu tava acostumado com uma coisa, conseguia mandar bem até. E na universidade era meio diferente, né? Tipo aqui, até os chamados "filhinho de papai" sofrem. Mas engenharia realmente é bem puxado. E aí foi aquele baque, né? Aliado com a falta de base, de estrutura tipo educacional. (Rafael)

O mais difícil é conciliar estágio com as disciplinas. Me organizar pra ler tudo, sabe? A quantidade de leitura é absurda e é difícil. É muito difícil. Você a cada momento de prova você fica tenso e é descontrolado porque você não sabe às vezes por onde começar a estudar. (Luiza)

Meu pai fala que quando eu passei pra faculdade eu mudei da água pro vinho, ate com relação aos meus estudos. Na escola, eu começava o ano super motivado "não.. vou estudar, vou tirar notas boas", no final dava tudo certo, mas chegava uma matéria que eu não ia muito bem, no final ia passando, ficava em recuperação em uma ou outra, mas passava. Ai cheguei aqui mudou totalmente. Sempre que da to lendo alguma coisa, to ate pegando coisa demais pra fazer. (Marcelo)

E para a maioria, a necessidade de uma organização autônoma de seus estudos, sem as figuras de autoridade das etapas anteriores de ensino como coordenadores de escolas, inspetores e diretores escolares cobrando um rendimento acadêmico, faz parte dos desafios encontrados nessa transição. Na universidade, os jovens sentem que precisam ser protagonistas de sua trajetória acadêmica.

Pra mim o mais difícil foi o primeiro período: muitas matérias e é diferente da escola onde sempre alguém que te cobra. É muita informação. Depois fui me adaptando, o segundo foi difícil também, o terceiro e quarto já foram melhores. (Julia) 
Então foi bem difícil nesse aspecto, nessa transição, de nota, de postura mesmo, de sair de aluno de ensino médio pra aluno de ensino superior, que é correr atrás, né? Porque ninguém vai ficar lá: óh... Tinha o coordenador, mandava email: “ óh, você tá assim”, liga pros pais. Você é seu responsável, então, não existe papai e mamãe pra vim aqui e conversar com o coordenador, pra falar, olha, meu filho... Ou ter atestado médico, passou mal, se vira, vem fazer prova, então acho que essa foi a maior dificuldade assim, pelo menos eu consegui. (Antonia)

Como as famílias de origem desses jovens moram em lugares distantes da universidade, muitos deles sentiram dificuldade de organizar os horário de aulas e estudos, principalmente no início da faculdade, para serem capazes de atender às exigências acadêmicas. A solução, para alguns deles, foi sair da casa dos pais durante a semana para ficarem mais próximos do campus universitário, e nos finais de semana, retornarem para seus locais de origem para ficarem com as suas respectivas famílias. Desta forma, conseguiram diminuir os efeitos negativos que o tempo longo dos deslocamentos traziam em suas rotinas acadêmicas.

Eu fui criando meu modelo de estudo, né? E como eu moro longe, eu fiz um quadro de horários, porque senão, não tinha como lidar, ainda mais acordando... Tendo que tá aqui sete horas da manhã morando em Niterói, madrugava, acordava 4:15am, vinha, e voltava e tinha que ter tudo regradinho, pra dar conta de tudo. Porque são sete matérias, se eu não me engano, no primeiro período, e você acha que é a mesma coisa que na escola você tem 11, mas inglês não conta, educação física não conta, artes não conta, e aqui tudo conta, e conta muito (risos) (Antonia)

Como eu moro em Caxias, os meus horários até o quarto período eram todos a tarde. Ai, no quarto, começou a ficar de manhã e como eu moro longe, no terceiro período eu comecei a conseguir alguma coisa pra ficar perto da faculdade até que consegui. Ai, hoje em dia, eu moro aqui perto durante a semana e final de semana eu volto pra ficar com meus pais. (Julia)

Eu não moro com meu pais durante a semana, fico sozinha agora então... tem que ficar sozinha, tem que ficar se deslocando Campo Grande-Gávea todo final de semana com mala... é uma prova. Eu morei em 2 republicas e morei com 2 amigas. Eu morei: republica, republica, amiga, republica amiga e eu (sozinha) (Gisele)

Ingressar na universidade é um importante passo e a manutenção no curso aparece como um desafio para esses jovens de perfil filantrópico ao longo do curso de graduação. Os custos de transporte, alimentação e aquisição de material didático sobrecarregam o orçamento familiar, em muitos casos. A solução encontrada pelos jovens entrevistados, na maior parte das vezes, é conseguir um trabalho ou estágio para complementar os recursos financeiros da família. 
Assim, por mais que minha mãe desse muito apoio na questão financeira, a gente tinha dificuldade também, de ter, porque eu passava quase o dia inteiro aqui, e as vezes tinha, depois que começou os estágios, e essa questão de ficar indo em vários lugares, e aí eu tinha que me alimentar no meio disso, tinha que ter mais dinheiro pra passagem, e isso foi um pouco difícil. E acabava assim, claro que a minha mãe não deixava faltar, mas acabava também que tirando, sei lá, as vezes eu precisava de uma roupa, também não tinha dinheiro pra comprar roupa. (...) Eu comecei também, comecei a pegas as crianças da rua, dar aula de explicação, essas coisas, pra tentar tirar algum dinheirinho também. (Luciana)

E aí depois eu tive que, a grana ficou curta, acabou e eu tive que começar a fazer um estágio, trabalhar, procurar um trabalho. E consegui um estágio na área de mecânica mesmo, na área de refrigeração e tal. Então o tempo pro estudo, o estudo ficou meio que comprometido, entendeu? (Rafael)

O meu pai me cobra que eu tenho que trabalhar (...) mais pra me sustentar. Apoio financeiro tenho mais do meu avô, do meu pai não... E uso o dinheiro que eu consegui juntar do meu trabalho. Que eu trabalhei durante muito tempo, quase dois anos com a faculdade, em loja. (Nathalia)

Pesquisas realizadas com jovens universitários no Brasil (SANTOS, 2012; RIBEIRO \& BOLSONI-SILVA, 2011; BOLSONI-SILVA ET AL, 2010; GOMES \& SOARES, 2013; SANTOS ET AL, 2013; OLIVEIRA \& DIAS, 2013; BARDAGI \& HUTZ, 2008; GUERREIRO-CASANOVA \& POLYDORO, 2010) apontam a entrada no ensino superior como um momento de transição multidimensional e complexo. $\mathrm{O}$ caminho universitário demanda uma adaptação constante dos sujeitos frente a desafios acadêmicos, pessoais e sociais que se apresentam ao longo de suas trajetórias.

No âmbito acadêmico, ao ingressarem no ensino superior, se apresentam a esses alunos novas exigências de estudo, novas responsabilidades, novas estratégias de aprendizagem, além de adaptação a um novo ritmo de estudo, e a diferentes formas de avaliação (GUERREIRO-CASANOVA \& POLYDORO, 2010). Como destacam Soares e Del Prette (2015), na universidade as aulas são menos descritivas e detalhadas. Isso requer, portanto, maior autonomia por parte dos alunos no aprofundamento dos conteúdos passados pelos professores durante as aulas e maior investimento de tempo fora da sala de aula para aplicação e ampliação do conhecimento, como, por exemplo, leituras de textos científicos ou resoluções de exercícios complexos.

No caso de alunos universitários com perfil socioeconômico filantrópico, outros fatores podem tornar essa adaptação ainda mais complexa como: base 
escolar deficiente nos níveis anteriores de escolarização ou a necessidade que muitos deles sentem de iniciar um estágio ou trabalho ainda nos períodos iniciais da faculdade para ajudar a custear sua permanência na universidade ou para complementar a renda familiar (SANTOS, 2012; ROCHA, 2008). Além disso, em pesquisa com esse público, Santos (2012) ressalta que os sujeitos apontam como um dos elementos mais desmotivadores as longas distancias e o tempo despendido nos trajetos percorridos. Somado à rotina de estágio ou de trabalho, as horas livres para dedicação ao estudo ou para atividades pessoais e de lazer ficam prejudicadas.

\section{Rede de apoio como suporte}

Para enfrentar as dificuldades vividas ao longo da trajetória universitária, os jovens entrevistados contaram com uma ampla de rede de apoio. Os pais aparecem como as figuras principais de suporte, acompanhados pela rede de amigos e pelo serviço de psicologia oferecido pela universidade. As figuras parentais são as mais frequentemente mencionadas quando se trata de ajuda na superação de desafios. Esse auxílio aparece tanto em forma de apoio financeiro, como também através de apoio moral e emocional.

E aí me ajudaram também, quando eu entrei, quando a minha grana acabou, entrei na PUC e juntei um dinheiro, que eu vendia jornais na época, como jornaleiro e aí, três, quatro meses depois a grana acabou, sabe? E aí meus pais me ajudaram, principalmente minha mãe. Minha mãe recebeu o bolsa família do meu irmão e aí foi a grana que ela tirou pra me ajudar, sabe? Até eu pegar esse estágio na engenharia mecânica. (Rafael)

O apoio financeiro foi da minha mãe. Meu pai também me ajudava quando dava, assim...é, com passagem, alguma coisa quando, logo no início quando precisava. Depois eu comecei a receber pelo fundo de apoio da universidade. E eu sempre digo que assim, se eu conseguir manter a faculdade até o fim foi graças a minha mãe mesmo, que o apoio maior foi dela, tanto apoio moral, emocional e financeiro. (Luciana)

Os participantes destacam as atitudes e palavras de apoio moral dos pais como grandes incentivadores diante das dificuldades encontradas ao longo de seu percurso acadêmico.

Os meus pais me ajudaram muito. Eles tem muita habilidade manual, meu pai por ser artista e minha mãe também tem habilidade, acho que foi ate por 
isso que escolhi design. Minha mãe ficava acordada ate tarde comigo, fazendo coisas manuais, ou não... qualquer coisa. Os dois dão apoio de formas diferentes: minha mãe fica comigo, do meu lado. Meu pai pergunta sempre como eu tô, se tô precisando de alguma coisa. (Julia)

É. Era mais assim, palavras de incentivo mesmo: "não, você vai estudar e vai conseguir". Porque às vezes ela fala: "ah, tô sentindo você muito pessimista", porque eu achava que eu não ia passar. Aí ela: "não, você vai passar sim". (Nathalia)

A minha mãe sempre fala. Até hoje ela fala. Eu fiz a prova (para concurso público) no domingo e a prova é pra uma vaga, aí ela fala: "minha filha, mas tudo é possível. Você sabe é possível, você já viu que é possível". É isso aí, por isso que eu vou tentar tudo. (Luciana)

A baixa escolarização dos pais não foi obstáculo para que eles oferecessem apoio aos seus filhos e se mostrassem disponíveis para ajudá-los. Apesar de não terem domínio sobre a cultura acadêmica universitária, esses pais se ofereceram como fonte de suporte, dando a esses jovens a segurança do acolhimento emocional necessário para enfrentar as dificuldades da trajetória universitária.

Agora... meus pais não tem bagagem teórica pra me ajudar a estudar psicologia, assim como quando eu estava em engenharia: meu pai olhava e dizia: bacana. Ele tava ali: tá tudo bem? Precisa de alguma coisa? Não é o que eles podem passar de conteúdo, mas é o que eles passam de segurança, é o "tô aqui". (Gisele)

(...) minha mãe, realmente, minha mãe me vê chorando ela fica, o que que eu faço? Você quer um chazinho de camomila? Eu faço um chazinho de camomila pra você. Você quer um floral? Vou lá, compro um floral pra você. Isso né, dá pra ela fazer ainda, agora o resto, a experiência, ela não sabe, então vem esse suporte. (Antonia)

Os resultados dessa pesquisa corroboram aquilo que é apontado por Santos (2012) em relação às figuras parentais com papel central no suporte aos filhos diante das dificuldades enfrentadas ao longo dos anos de graduação em pesquisa com jovens universitários de perfil socioeconômico filantrópico. Oliveira e Dias (2013), ao realizarem pesquisa com pais de universitários, apontam que, na visão dos genitores, o seu papel no desenvolvimento de carreira dos filhos durante a graduação consiste em oferecer apoio emocional e material. Comparando com os resultados de outra pesquisa, com jovens evadidos do ensino superior, em que Bardagi e Hutz (2008) apontam para a necessidade de uma maior aproximação familiar durante a graduação, pode-se pensar sobre a importância desse apoio parental. Os jovens que abandonaram os cursos apresentavam em comum a 
ausência de trocas com os pais sobre suas angústias, questões sobre a carreira ou vida universitária.

Os amigos também aparecem, nas entrevistas realizadas com os jovens de perfil filantrópico, como forte referência de apoio para enfrentar os momentos mais difíceis. As amizades que parecem ser significativas nesse processo podem ser tanto anteriores à entrada na universidade, como parte integrante da vivência acadêmica que permite a formação de novos grupos de convívio, desenvolvendo laços afetivos mais recentes nas vidas desses sujeitos. Talvez por esses amigos estarem mais próximos da realidade acadêmica desses jovens, possam entender bem suas questões e auxiliá-los nas soluções.

Nos momentos de confusão e ansiedade só os meus amigos que eu converso e tal. Amigos de fora, porque os meus amigos mais antigos são do ensino fundamental. Então, eu vou fazendo novas amizades, mas esses são... sabe? Os chaves. Então, eles me ajudam bastante. O Luiz, depois que a gente começou a namorar, também ajuda. (Luiza)

Eu também acho que se não fosse a rede eu também não teria conseguido. A gente acha que é uma coisa boba, né? Você fazer amizade com alguém, mas você ficar cinco anos num lugar que você não se sente pertencente a ele, e você não tem com quem falar é muito difícil, é muito complicado. Agora, graças a Deus, a rede que eu consegui construir aqui foi ótima. De me apoiar naquele, as vezes eu chorava: "aí eu não vou conseguir, não tá dando" e ter quem me apoiasse, nossa, nos trabalhos também, essas coisas mesmo da rotina da faculdade, né? (Luciana)

Eu saí pesquisando, falava com os veteranos, eu já tinha amigos que estudavam aqui, era só um período acima do meu, mas que já me deram um suporte muito grande, que aí disseram que tinham os grupos e sites na internet, que era pra gente correr pra achar monitoria, falar com professor, pegar email de professor, pra mandar email porque eles realmente respondem email, e procurar tudo, aula particular nos murais que tinham aula particular, e é isso, pegar os melhores livros, né, pegar resumo de aluno, estudar por prova antiga, e aí foi... (Antonia)

O serviço de orientação psicológica oferecido pela universidade também foi citado pelos entrevistados como uma fonte de apoio importante diante das dificuldades enfrentadas ao longo do percurso universitário. Os sujeitos parecem identificar o fator psicológico como tendo grande interferência em seu desempenho acadêmico e, por isso, o trabalho junto a profissionais especializados na área, parece favorecer a possibilidade de elaboração e o enfrentamento de questões de adaptação que, por algum motivo, eles tiveram dificuldades de superar sozinhos até aquele momento. 
O psicológico também é difícil porque estudar também é difícil, requer seu tempo, abrir mão de outras coisas para estar estudando. Um apoio psicológico ajuda também da pessoa poder falar sobre as dificuldades, sobre as escolhas. (Julia)

Eu acabei descobrindo aqui depois, né? Que foi esse serviço de psicologia. Eu acho que também uma ajuda assim psicológica é muito importante. Porque as vezes o financeiro, tá, você consegue dá um jeito no financeiro, mas as vezes o psicológico não vai bem. (...) E tinha muita coisa pra dar conta, foi até quando eu procurei uma ajuda aqui. O meu amigo ele já vinha, e ele fazia acompanhamento com você. Aí ele que me indicou: "ah lá tem psicóloga e tal, conversa com ela". Foi quando eu tava meio enrolada no período. Aí eu vim, perguntei ali e me marcaram. (Luciana)

$\mathrm{Na}$ verdade queria ter conhecido essa parte das psicólogas antes. Queria ter conhecido bem mais cedo. Eu acho que tem que ter esse acompanhamento. Ajuda com escuta, organização e perspectiva. Porque às vezes a gente ta passando por tanta coisa que parece que não sai do papel ou da cabeça. Aí o jeito de organizar pra chegar naquilo. E não ficar tipo: ah. Tem muita coisa tem muita coisa parado, estrangulado naquilo. Porque muitas vezes isso aconteceu comigo de ter muita coisa pra estudar e acabar não fazendo nada porque começava aqui, não entendia nada e via que tinha mais muita coisa e acabava não fazendo nada. Paralisava. E você vê que isso não acontece só com você sabe? Você acaba achando que é a pessoa mais estranha do mundo porque não é possível. Como é que fulano de tal consegue, sabe? Então seria bom ter tido isso mais cedo. (Luiza)

De acordo com Gomes e Soares (2013), a competência em utilizar os recursos pessoais e institucionais pode ajudar o jovem a responder às demandas que se apresentam na vida universitária e se manter em seus objetivos. A avaliação das próprias experiências vividas ao longo da trajetória universitária, tende também a ser feita de forma mais favorável por aqueles que acessam positivamente esses recursos.

Um ambiente universitário acolhedor pode ajudar, principalmente os estudantes recém-chegados, no desenvolvimento e utilização de seus potenciais pessoais (CUNHA \& CARRILHO, 2005), assim como, esse ambiente se modifica na relação com os novos alunos que trazem necessidades diferentes de ajustamento (HUTZ, MIDGETT \& BALDRIDGE, 2010). De acordo com Soares e Del Prette (2015), os processos de integração dos alunos, entre os estudantes e seus professores, gestores e funcionários da instituição podem ser influenciadas pelas condições da infraestrutura institucional. O contexto da instituição pode promover ou dificultar comportamentos mais adaptativos, e pode promover ou inibir relações e experiências sociais agregadoras. Santos (2012) ressalta que a 
instituição de ensino e seus serviços de apoio são a segunda esfera de apoio mais procurada por jovens universitários de perfil filantrópico diante de dificuldades ao longo da graduação, estando atrás apenas dos pais.

\section{Ampliação dos horizontes}

Analisando as entrevistas, pode-se perceber que o percurso no ensino superior tem significados que ultrapassam as questões acadêmicas. Os seguintes significados foram destacados nos discursos dos sujeitos: a abertura de novos horizontes, a possibilidade de tornar-se protagonista e o lugar de exemplo. Cursar o ensino superior parece ser reconhecido pelos jovens entrevistados como um meio de abertura para novas experiências e novas formas de pensar. Os jovens destacam que o ingresso na universidade permitiu o acesso ao contato com diferentes pessoas, lugares e oportunidades, o que enriquece a forma de pensarem as escolhas profissionais futuras.

A faculdade, como meu avô diz, muda e amplia seus horizontes, te da uma outra percepção de mundo, te abre um leque de possibilidades que são possibilidades, a vida pode me levar a não escolher nenhuma delas, eu acho que por enquanto acredito que não, que eu vá exercer minha profissão, mas... (Gisele)

(...) as saídas de campo que eu fiz e eu comecei a descobrir mais a cidade, né? Porque senão eu teria ficado aqui na zona sul pra sempre e não teria conhecido nada e, mas agora eu conheço vários lugares, sabe? Que eu nunca imaginaria ir e tem trilha que eu nunca pensei que eu fosse começar a fazer ... é.. não sei. É uma visão de mundo muito diferente que eu tô tendo agora. (...) Penso em morar fora talvez. Tentar alguma coisa. Não sei. Estudar lá fora, tentar alguma coisa. Fazer um intercâmbio.. sei lá. Eu tenho esse negocio muito forte de querer ver o mundo, sabe? Querer conhecer novas culturas, novos lugares, pessoas. Com certeza a universidade contribuiu pra que eu abrisse esse horizonte assim, sabe? (Luiza)

Entrei na universidade era meio que garotão, não tinha meio que consciência das coisas. Uma coisa que eu achei muito interessante aqui, antes de entrar na universidade eu era muito... Meus pais pertencem a uma igreja que é totalmente protestante ali, pentecostal, sabe? Eles meio que manipulam muito a mente das pessoas, então eu fazia parte também da igreja. Antes de entrar na universidade eu tinha minhas dúvidas: porque disso, porque daquilo. E ninguém nunca respondia... Até que na universidade tive contato com pessoas diferentes eu pude ver que, sei lá, que pra ser cristão, amar a Deus, não precisava nada de me privar de $\mathrm{N}$ coisas, sabe? Eu amadureci muito esse meu lado, tanto intelectual... Acho que, assim, amadureci muito a minha vida. Hoje eu consigo, assim, olhar pra trás e ver tipo o quanto eu estava errado em relação a certos aspectos da vida. Não era bem aquilo, aquela não era a única verdade, sabe? Tenho um pensamento mais crítico agora. (Rafael) 
O ingresso na universidade parece trazer para os jovens entrevistados uma expectativa por uma colocação no mercado de trabalho que pode ajudá-los a retribuir, de alguma forma, o investimento que suas famílias fizeram em seus estudos. As conquistas provenientes dessa trajetória parecem envolver não só os sujeitos individualmente, mas também suas famílias. A possibilidade de se tornarem protagonistas sociais, traçando um caminho de independência, principalmente financeira, e que os permita ainda colaborar com suas famílias parece atribuir a esses jovens um senso positivo de si mesmos. A possibilidade de tornarem-se agentes de mudanças em seu próprio meio aparece como um motivador na sua trajetória acadêmica.

Não penso em parar de estudar. Quero viajar e estudar fora, mas não por muito tempo, porque quero estar perto da minha família. Eu penso em ter um namorado, mas também penso em ter alguém que esteja no mesmo caminho que eu, que pense em estudar, em viajar, em trabalhar, em ter um emprego legal. Penso em ter minha casa, mas que eu possa ter independência, ter minha casa que eu possa me sustentar. Isso é uma coisa que eu almejo muito, acho que meu pai já fez muita coisa por mim, tá na hora de eu fazer sozinha. (Julia)

Oportunidade de mudar minha vida, de fazer a diferença. Eu acho que eu sempre quis isso, fazer a diferença, porque tanta gente já fez por mim que agora eu quero fazer pelos outros, entende? Então, o ensino superior é a porta, é a primeira porta que eu posso pra ajudar as pessoas, pra ajudar minha família, essa quantidade de gente toda, que já tá assim: "ah se forma aí óh, pra você me ajudar, pra você construir minha casa, pra você não sei o que, me arranjar um emprego na sua empresa". Falei: "tá gente, tá bom, vamos um passinho de cada vez". (Antonia)

Na verdade eu já ajudo, de uma forma ou de outra, mas eu quero ajudar mais. Tipo, minha tia, tipo, já tem praticamente 60 anos e ainda trabalha como doméstica, sabe? E é uma tia que sempre está disposta a ajudar todo mundo, e eu fico olhando assim, poxa, ela não tá mais na idade de ficar limpando o chão e sofrer humilhações. Mas tipo, é uma coisa que me chateia bastante, magoa, mas, infelizmente ainda não posso, sabe? Ainda não posso abraçar, sabe? Abraçar o mundo é algo impossível. Mas quem sabe um dia eu fale: não tia, pare de trabalhar e fica tranquila aí que a partir de, daqui pra frente eu posso dar conta, sabe? (Rafael)

Cursar a universidade parece ter para esses jovens entrevistados ainda a chance de serem exemplo para outras pessoas na família, principalmente para os mais jovens. Parece que, dar o exemplo do estudo e servir como modelo para primos ou irmãos, traz também uma valorização da própria história desses sujeitos que foram entrevistados. Durante as entrevistas, quando falavam sobre esse ponto, pode-se sentir um sentimento de orgulho, uma valorização de si mesmos, um 
incentivo à própria auto estima ao falarem de como outros se espelham neles. Estar nesse lugar de referência parece ampliar de forma positiva o olhar desses jovens para si mesmos e para suas capacidades.

Então tinha essa carga familiar bem grande na faculdade. E também a responsabilidade que os tios colocavam em mim como exemplo pra os primos. Esse meu primo que é mais velho, ele faz engenharia mecânica, ele começou o curso técnico de mecânica porque ele viu que eu tava fazendo, viu o que eu estava fazendo, ele começou a gostar. Ele: "po, Gisele é mais nova, tá fazendo, tá correndo atrás, eu vou fazer também". Ai ele escolheu o mesmo curso. Ai quando eu fui pra engenharia ele também, escolheu o mesmo curso. (Gisele)

Engraçado que tem mô galera que, tipo, me tem como exemplo, sabe? Às vezes, quando eu penso em desistir eu até penso neles. Tipo: "não, sabe"? Até meu irmão mesmo, sabe? Meu irmão, tipo, foi um caso muito sério, porque eu ficava muito preocupado com ele, só ficava na rua, pegava o carro dos outros pra andar, moto pra cima e pra baixo e na região violenta eu ficava com muito medo de acontecer algo com ele. E aí, graças a Deus, ele mudou assim, como da água pro vinho, sabe? Tá estudando, tá batalhando e conseguiu ser jovem aprendiz aqui (dentro da universidade), enfim, e tá na universidade comigo todos os dias praticamente. (Rafael)

Minha madrinha diz sempre que eu sou muito responsável, então quando você é muito responsável você se cobra muito, então é por isso que eu devo ter esse valor pelo estudo, e por tudo que eu já disse. Por querer dar esse suporte. Antes era só eu e minha mãe, então até a quarta série, que foi quando meu irmão nasceu, eu tava assim, de boa, sabe? É pra mim. Só que agora, tem uma criança que se espelha em mim. Então, se eu não estudar, ele vai achar que também não pode estudar, e ele só tem 11 anos, entendeu? Então eu acho que daí que começou a ficar, não vou dizer que pior, mas, aumentou essa minha cobrança.(...). Então acho que é isso, quero ser exemplo, ainda mais pra ele que quer fazer engenharia também. Ele quer fazer engenharia mecânica, ele ama carro. (Antonia)

A entrada no ensino superior gera níveis elevados de expectativas relacionadas ao futuro que podem vir a se confirmar ou gerar frustração, dependendo do resultado dos recursos de cada sujeito para se ajustar ao novo contexto escolar. Aqueles que conseguem transpor as dificuldades dos períodos iniciais de adaptação, experimentam modificações em seu senso crítico e maneira de pensar ao longo dos anos de graduação. É uma visão de mundo que se amplia. Ou seja, os alunos que concluem o curso tornam-se pensadores mais sofisticados a respeito da sociedade em que vivem (GOMES \& SOARES, 2013; FELICETTI, CABRERA \& COSTA-MOROSINI, 2014).

Em pesquisas realizadas com jovens formados ou em formação na condição de bolsistas no ensino superior, algumas percepções sobre o impacto da conclusão do curso em suas vidas foram compartilhados por eles. Os resultados 
apontam que a grande maioria percebeu mudanças positivas na motivação e na autoestima; a ampliação das redes sociais; o desejo de continuar estudando e se especializando; e a influência na motivação de outros familiares a iniciarem ou darem prosseguimento aos estudos (AMARAL \& OLIVEIRA, 2011; FELICETTI, 2014; MONGIM, 2015).

\section{3}

\section{Considerações Finais}

Os programas sociais, frutos de iniciativas privadas ou governamentais, aparecem na pauta de muitas instituições que trabalham em favor da diminuição das diferenças socioculturais e da ampliação de oportunidades na sociedade brasileira. O campo da educação, reconhecidamente um campo fértil de transformações cognitivas e sociais, se apresenta como uma área de grande investimento desses programas. Bolsas de estudos ofertadas em universidades brasileiras ampliam o acesso à educação superior de jovens de perfil socioeconômico filantrópico. A visão dos jovens que participaram dessa pesquisa sobre os programas sociais é positiva, identificando neles um facilitador no caminho de seu desenvolvimento e propiciadores de oportunidades de grandes conquistas.

O caminho acadêmico, no entanto, apresenta alguns obstáculos para esses jovens que incluem uma necessidade de adaptação ao novo sistema escolar, com a transição da postura de aluno do ensino médio para aluno do ensino superior. Outros fatores mais relacionados à condição socioeconômica das famílias desses bolsistas se apresentam como desafios a serem superados ao longo da graduação, como a distância entre o campus universitário e seus locais de residência e questões financeiras referentes à sua manutenção na universidade (passagens, xerox, alimentação, entre outros). Para a superação dessas dificuldades, esses jovens contam com uma ampla rede de apoio que inclui os pais, amigos e um serviço de apoio oferecido pela própria instituição.

O acesso ao ensino superior e a possibilidade de conquistar um diploma universitário parecem representar para esses jovens algo muito além de maiores possibilidades de emprego e de remuneração. $O$ ingresso na universidade e o 
convívio na ambiente acadêmico trazem a abertura de novos horizontes, possibilitando uma ampliada visão de mundo e um senso critico mais apurado. Ampliam ainda a visão de si mesmos como protagonistas de suas histórias, de suas capacidades e os colocam como exemplos a serem seguidos por outras pessoas de seu convívio social e familiar. Servir de referência parece trazer para esses jovens uma valorização de sua própria trajetória e um senso de compromisso com o coletivo, na medida em que existem outras pessoas se espelhando em seus comportamentos e eles desejam que os benefícios, que receberam e dos quais usufruíram com tanta propriedade, se estendam a outras pessoas. 


\section{Conclusões}

A educação tem sido vista como campo fértil de combate às desigualdades sociais no Brasil nos últimos anos. O ensino superior parece ser a área mais efetiva na geração de oportunidades para uma população que historicamente teve menos acesso à universidade por suas condições socioeconômicas. Com os amplos programas sociais desenvolvidos tanto pelo governo quanto pelas inciativas privadas, jovens de perfil socioeconômico filantrópico tem sido inseridos no meio acadêmico através dos mais diversos cursos de graduação.

Esse estudo trouxe considerações acerca dessa experiência universitária, desde sua idealização como um projeto educacional até as vivências que esses jovens tiveram ao longo do curso de graduação. No que diz respeito ao projeto educacional, evidenciou-se a forte influência social e familiar, especialmente dos pais nesse projeto. A educação aparece como um valor muito importante nessas famílias, transmitido aos jovens, independentemente da formação acadêmica dos pais, que por algumas vezes não ultrapassa o ensino fundamental.

A grande relevância do valor do estudo para esses jovens e suas famílias reside na possibilidade de ampliação de oportunidades que uma formação acadêmica superior pode gerar. A partir do diploma, que é socialmente valorizado, a formação superior pode ser o princípio de uma ascensão e de uma mobilidade social, favorecendo melhores oportunidades de trabalho, carreira e remuneração aos jovens do que aquelas às quais as gerações anteriores tiveram acesso. Além da formação acadêmica, os jovens reconhecem que o percurso no ensino superior amplia os seus horizontes, permite viverem novas experiências, conhecerem novas pessoas e novas formas de olhar o mundo.

Muitos desses jovens são os primeiros de suas famílias a cursar o ensino superior. Esse pioneirismo traz um sentido de valorização da própria história e também da herança familiar que esses sujeitos receberam. O senso de autoestima e autoeficácia aumenta na medida em que eles se percebem muitas vezes como protagonistas sociais em suas vidas, na de suas famílias e de suas comunidades. Alguns pais e mães, ao verem o filho alcançando sua formação e realizando aquilo que para eles pareceu difícil ou impossível em outro momento de suas vidas, 
muitas vezes por questões financeiras e sociais, acabam se motivando a retomar seus próprios estudos. As gerações mais novas de primos, irmãos e vizinhos também se espelham nas trajetórias desses jovens e isso traz também um senso de responsabilidade com o outro, tornando o projeto educacional coletivo e não somente individual.

Muitos desses pais que não prosseguiram com seus estudos para níveis mais avançados da formação acadêmica interromperam seus projetos por questões sociais e financeiras como necessidade de trabalhar para geração de renda, ou necessidade de priorizar o tempo nos cuidados dos filhos e da família. Comparando a geração dos pais com a geração dos jovens que participaram da pesquisa, os sujeitos se percebem tendo mais oportunidade do que seus pais tiveram. A maioria atribui aos programas sociais a chance de ter uma vida acadêmica mais longa, e com isso poderem também ter melhores oportunidades de trabalho e maiores conquistas no futuro. A visão dos jovens que participam desses programas é positiva, eles acreditam que possa ser um caminho para a diminuição das desigualdades sociais de nosso país.

Os jovens que são beneficiados por programas de bolsas e auxílios demonstram solidariedade social e um desejo de que outras pessoas se beneficiem também das oportunidades que eles tiveram. No entanto, é claro para esses jovens que a postura de cada um diante da oportunidade que recebe é o que determina um caminho de sucesso. Não basta conseguir um benefício, cada um precisa se envolver e se comprometer com a vida acadêmica para alcançar seus objetivos finais.

A concessão de uma bolsa de estudos é o início do percurso universitário desses jovens. Ao longo do curso de graduação, eles enfrentam inúmeros desafios que incluem a transição do ensino médio para o ensino superior, as longas distâncias percorridas entre a universidade e seus locais de residência e a dificuldade financeira para permanência no ensino superior. A entrada na universidade traz para os jovens, de modo geral, necessidade de adaptação complexa, com novas formas de cobranças, necessidade de postura mais proativa, relações com grupos bastante diversificados de pessoas, novas relações institucionais, entre outras exigências para uma boa vivência acadêmica. Além desses processos, o jovem de perfil socioeconômico filantrópico enfrenta ainda desafios de cunho social e financeiro. Apesar de termos grandes avanços no 
Brasil com relação às políticas de acesso ao ensino superior, a permanência dos alunos ainda é um grande desafio. Alguns desses jovens começam a trabalhar ou estagiar nos períodos iniciais da faculdade para gerarem recursos para sua manutenção e a grande maioria recebe o investimento financeiro parental frente a esse desafio.

Os pais são as figuras mais citadas quando se trata de apoio ao projeto educacional universitário. $\mathrm{O}$ apoio parental é reconhecido por esses jovens como sendo de natureza financeira, moral e emocional. Diante dos desafios enfrentados ao longo da universidade, os pais se tornam os grandes incentivadores com palavras de apoio, tempo disponível para ouvir e ajudar os filhos, e sendo representantes de uma segurança emocional que ajuda esses filhos a se manterem firmes em seu propósito. Apesar de muitos não terem o domínio da cultura acadêmica ou vivências dessa natureza, os pais se oferecem como principal fonte de apoio para os filhos.

A rede de apoio desses jovens inclui ainda os amigos, alguns anteriores à vida universitária e outros conquistados durante o curso de graduação, e o apoio institucional. Os amigos, talvez por estarem mais próximos à realidade desses jovens, se tornam importantes fontes de apoio, compartilhando muitas vezes as mesmas dificuldades e uma linguagem comum ao meio acadêmico, podendo compartilhar angústias sobre certas disciplinas, sobre o futuro profissional, e as soluções que cada um foi encontrando ao longo do caminho.

O principal apoio institucional citado pelos participantes da pesquisa foi o Serviço Comunitário de Orientação Psicológica (PSICOM), que busca acolher as demandas emocionais dos alunos e junto a cada um deles, traçar estratégias de enfrentamento das dificuldades encontradas. Foi evidenciado por esses jovens o grande impacto que os aspectos psicológicos exercem na vida acadêmica. Foi ressaltado por eles que, muitas vezes, o apoio psicológico ajuda a organizar todas as mudanças pelas quais eles estão passando. É uma forma de fortalecê-los para lidar com as pressões e as exigências da vida acadêmica.

O PSICOM trabalha com o princípio de que todo ser humano tem, dentro de si, o potencial para solucionar os seus problemas. Nosso trabalho consiste em ajudar os alunos que nos procuram a enxergar suas habilidades e potencializar seus recursos de enfrentamento, que acabam por gerar nesses jovens uma apropriação de suas forças internas e uma maior apreciação de si mesmos. 
Essa pesquisa foi idealizada a partir da apreciação e da admiração das trajetórias dos alunos que foram ou são atendidos por nós no PSICOM. Acreditamos que com as experiências de alguns, podemos aprender muito sobre o coletivo e inspirar outras pessoas a se identificarem com essas histórias, a continuar investindo naquilo que desejam alcançar, vendo que é possível serem bem-sucedidos em seus projetos.

Os resultados deste estudo devem ser compreendidos considerando alguns aspectos de sua limitação. A amostra é de uma única instituição e foi selecionada por conveniência. Os resultados obtidos indicam a relevância de refletirmos sobre os significados dos programas sociais, a importância do projeto educacional na vida dos jovens e os recursos disponíveis, bem como sobre aqueles que ainda podem ser criados, para auxiliar na manutenção e na permanência desses jovens de perfil socioeconômico filantrópico no ensino superior. Pretendemos ampliar a discussão dessas temáticas em estudos futuros, e enxergamos espaço para o desenvolvimento de estudos mais aprofundados sobre os temas citados e a ampliação da discussão sob novas perspectivas. 


\section{Referências bibliográficas}

ABDAL, A. NAVARRA, J. Uni por Uni, eu escolhi a que era do lado da minha casa. Novos estudos, n.99, p.65-87. 2014.

ALMEIDA, W. Os herdeiros e os bolsistas do prouni na cidade de São Paulo. Educação e Sociedade, v. 36, n.130, p. 85-100. 2015.

ALMEIDA, M. E. G. G. \& MAGALHÃES, A. S. Escolha profissional na contemporaneidade: projeto individual e projeto familiar. Revista Brasileira de Orientação Profissional, n.12 (2), p.205-214. 2011.

ALMEIDA, M., ALMEIDA, F. \& MELO-SILVA, L. Influência dos pais no processo de escolha profissional dos filhos: uma revisão da literatura. Psico-USF, n.16 (1), p.75-85. 2011.

ALMEIDA, M. \& PINHO, L. Adolescência, família e escolhas: implicações na orientação profissional. Psic. Clin, n.20 (2), p.173- 184. 2008.

AMARAL, D.; OLIVEIRA, F. O ProUni e a conclusão do ensino superior: questões introdutórias sobre os egressos do programa na zona oeste do Rio de Janeiro. Ensaio: Avaliação e Políticas Públicas em Educação, v. 19, n. 70, p. 21-42. 2011.

AMARAL, D.; OLIVEIRA, F. O Prouni e a conclusão do ensino superior: novas trajetórias pessoais e profissionais dos egressos. Avaliação e Políticas Públicas em Educação, v. 19, n. 73, p. 861-890. 2011.

ANDRADE, T. A família e a estruturação ocupacional do indivíduo. In: LEVENFUS, Rosane e cols. Psicodinâmica da escolha profissional. Porto Alegre: Artes Médicas, 1997. p.123-134. 
ASSIS, A; SANABIO, M; MAGALDI, C; MACHADO, C. As políticas de assistência estudantil: experiências comparadas em universidades públicas brasileiras. Revista Gestão Universitária na América Latina - GUAL, v.6, n.4. p.125-146. 2013.

BACAL, M.E.A. Lealdades visíveis e invisíveis: um estudo sobre a transmissão geracional da profissão na família. Rio de Janeiro, 2013. 200p. Tese de Doutorado em Psicologia Clínica - Pontifícia Universidade Católica do Rio de Janeiro.

BARDAGI, M. \& HUTZ, C. Apoio parental percebido no contexto da escolha inicial e da evasão de curso universitário. Revista Brasileira de Orientação Profissional, n.9(2), p.31-44. 2008.

BARDIN, L. Análise de conteúdo. São Paulo: Edições 70, 2011.

BOLSONI-SILVA, A. ; LOUREIRO, S.; OLIVEIRA, C. Caracterização das habilidades sociais de universitários. Contextos clínicos, v.3, n.1, p. 62-75. 2010.

BORNHOLDT, E; WAGNER, A. A gravidez à luz da perspectiva paterna: aspectos relativos à transgeracionalidade. In: WAGNER, A. (Org.). Como se perpetua a família? A transmissão dos modelos familiares. Porto alegre: Edipucrs, 2005. p. 81-92.

BOSZORMENYI-NAGY, I.; SPARK, G. Invisible loyalties: Reciprocity in intergenerational family therapy. Nova York: Harper \& Row, 1984.

BOWEN, M. Family psychotherapy with schizophrenia in the hospital and in private practice. In: I. BOSZORMENYI-NAGY; J. L. Framo (Eds.). Intensive family therapy: theoretical and practical aspects. New York: Harper\& Row, 1965. p.213-243.

BUCHER-MALUSCHKE, J. Do transgeracional na perspectiva sistêmica à transmissão psíquica entre as gerações na perspectiva da psicanálise. In: ,PENSO 
M. \& COSTA, L. (Orgs). A transmissão geracional em diferentes contextos: da pesquisa à intervenção. São Paulo: Summus Editorial, 2008. p.76-96.

CARRETEIRO, T. \& FREIRE, L. De mãe para filha: a transmissão familiar em questão. Psic. Clin, n. 18(1), p.179-191. 2006.

CASALI, A.; MATTOS, M. Análise de estudos e pesquisas sobre o sentido social do programa Universidade para Todos (PROUNI). Ensaio: Avaliação e Políticas Públicas em Educação, v.23, n. 88, p. 681-716. 2015.

CUNHA, S.; CARRILHO, D. O processo de adaptação ao Ensino Superior e o rendimento acadêmico. Psicologia Escolar e Educacional, n.9(2), p.215-224. 2005.

FALCKE, D. \& WAGNER, A. A dinâmica familiar e o fenômeno da transgeracionalidade: definição de conceitos. In: WAGNER, A. (Org.). Como se perpetua a família? A transmissão dos modelos familiares. Porto alegre: Edipucrs, 2005. p. 25-44.

FELICETTI, V.; CABRERA, A.; COSTA-MOROSINI, M. Aluno ProUni: impacto na instituição de educação superior e na sociedade. Revista Iberoamericana de Educación Superior, v.V, n.13, p.21-39. 2014.

FELICETTI, V. Comprometimento do aluno ProUni: acesso, persistência e formação acadêmica. Rev. bras. Estud. Pedagog, v. 95, n. 241, p. 526543. 2014.

FERNANDES, F. \& GONÇALVES, C. Escolhas vocacionais dos jovens: projetos pessoais ou projetos familiares? Revista AMAzônica, n.8 (1), p.171-182. 2012.

FILOMENO, K. Mitos familiares e escolha profissional: uma visão sistêmica. São Paulo: Vetor Editora, 2005. 
GOMES, G.; SOARES, A. Inteligência, habilidades sociais e expectativas acadêmicas no desempenho de estudantes universitários. Psicologia: Reflexão e Crítica, n.26(4), p.780-789. 2013.

GUERREIRO-CASANOVA, D.; POLYDORO, S. Integração ao ensino superior: relações ao longo do primeiro ano de graduação. Psicologia Ensino \& Formação, n.1(2), p.85-96. 2010.

HUTZ, A.; MIDGETT. B.; BALDRIDGE, M. O que aprendemos nos Estados Unidos com a experiência de inclusão de estudantes minoritários na universidade: sugestões para apoiar estudantes cotistas em universidades brasileiras. In: HUTZ, C. Avanços em psicologia comunitária e intervenções psicossociais. São Paulo: Casa do Psicólogo, 2010. p.265-296.

INEP. Notas Estatísticas Censo da Educação Superior. Brasilia: INEP/Ministério da educação, 2014.

KROM, M. Família e mitos: prevenção e terapia: resgatando histórias. São Paulo: Summus Editorial, 2000.

Lei n. 12.101, de 27 de novembro de 2009. Dispõe sobre a certificação das entidades beneficentes de assistência social; regula os procedimentos de isenção de contribuições para a seguridade social; altera a Lei no 8.742, de 7 de dezembro de 1993; revoga dispositivos das Leis nos 8.212, de 24 de julho de 1991, 9.429, de 26 de dezembro de 1996, 9.732, de 11 de dezembro de 1998, 10.684, de 30 de maio de 2003, e da Medida Provisória no 2.187-13, de 24 de agosto de 2001; e dá outras providências. Diário Oficial da República Federativa do Brasil. Brasília, DF, 27 de novembro de 2009 . Disponível em: <http://www.planalto.gov.br/ccivil_03/_ato2007-2010/2009/lei/112101.htm>. Acesso em: 22 mar.2016.

LISBOA, A; FÉRES-CARNEIRO, T. \& MAGALHAES, A. Transmissão psíquica geracional familiar no adoecimento somático. Arquivos Brasileiros de Psicologia, n.63 (2), p.1-121. 2011. 
MANDELLI, M. T.; SOARES, D. H. P. \& LISBOA, M. D. Juventude e projeto de vida: novas perspectivas em orientação profissional. Arquivos Brasileiros de Psicologia, 63(no. spe.), p.49-57. 2011.

MATOS, A. Intervenção sistêmica com famílias alcoólicas. Lisboa, 2015. 111p. Dissertação de Mestrado - ISPA - Instituto Universitário.

MONGIM, A. Crescimento pessoal, mediação e sacrifício: itinerários sociais de estudantes beneficiários do prouni. Educação e Sociedade, v. 36, n. 133, p. 927943. 2015.

MONTEIRO, C. \& TEIXEIRA, L. Família e tecnologias reprodutivas: considerações sobre a transmissão psíquica geracional. Arquivos Brasileiros de Psicologia, n.63 (2), p.1-121. 2011.

NIEROTKA, R.; TREVISOL, J. Os jovens das camadas populares na universidade pública: acesso e permanência. Revista Katálysis, v. 19, n. 1, p. 2232. 2016.

OLIVEIRA, C., DIAS, A. Percepções parentais sobre sua participação no desenvolvimento profissional dos filhos universitários. Revista Brasileira de Orientação Profissional, v.14, n.1, p.61-72. 2013.

OLIVEIRA, E.; MOLINA, R. A ampliação da base social da educação superior no contexto do Centro Universitário do Leste de Minas Gerais: o caso do ProUni. R. bras. Est. Pedag. v. 93, n. 235, p. 743-769. 2012.

PELLEGRINI, P., SILVA, I., BARRETO, M. \& CREPALDI, M. Diferenciação do adulto jovem: um estudo de caso em atendimento familiar. Pensando famílias, n.19 (1), p.114-129. 2015.

RAMOS, O. \& OLIVEIRA, K. Transgeracionalidade percebida nos casos de maus-tratos. In: Penso, M. \& COSTA, L. (Org). A transmissão geracional em 
diferentes contextos: da pesquisa à intervenção. São Paulo: Summus Editorial, 2008. p.99-122.

REIS, L. P. C. Família, relações intergeracionais e projetos de vida. Revista Diálogos Possíveis, n.12 (1), p.174-186. 2013.

RIBEIRO, M. A. A influência psicossocial da família e da escola no projeto de vida no trabalho dos jovens. Pesquisa e Práticas Psicossociais, n.5(1), p.120-130. 2010.

RIBEIRO, D.; BOLSONI-SILVA, A. Potencialidades e dificuldades interpessoais de universitários: estudo de caracterização. Acta Comportamentalia, n.19(2), p.205-224. 2011.

ROCHA, M. Processo de inclusão ilusória: a condição do jovem bolsista universitário. Porto Alegre, 2008. 264f. Tese de doutorado em Serviço Social Pontifícia Universidade Católica do Rio Grande do Sul.

ROSSETTO, C.; GONÇALVES, F. Equidade na Educação Superior no Brasil: Uma Análise Multinomial das Políticas Públicas de Acesso. Revista de Ciências Sociais, v.58, n3, pp.791-824. 2015.

SALVADOR, A. A gênese da política de ação afirmativa da PUC-Rio. Uma parceria entre Universidade e Movimento Social. Desigualdade e Diversidade, n.5, p.125-148. 2009.

SAlVADOR, A. C., HERINGER, R. R. \& OLIVEIRA, A. J. B. Políticas de ação afirmativa: Direito e reconhecimento. O Social em questão, n.17 (32), p.9-16. 2014.

SANTOS, C. Ações afirmativas no ensino superior: análise do perfil socioeconômico e da experiência universitária de bolsistas do ProUni na PUCRio. Revista brasileira de estudos pedagógicos, v.93, n.235, p.770-790. 2012. 
SANTOS, B. \& CERVENY, C. Repetição de nome próprio: vínculos familiares e culturais. Revista do NESME, n.10 (1), p.1-37. 2013.

SANTOS, A.; POLYDORO, S.; SCORTEGAGNA, S. Integração ao ensino superior e satisfação acadêmica em universitários. Psicologia: ciência e profissão, v.33, n.4, p.780-793. 2013.

SARAIVA, L.; NUNES, A. A efetividade de programas sociais de acesso à educação superior: o caso do ProUni. Revista de administração pública, v.45, p.947-964. 2011.

SARMENTO, D. O negro e a igualdade no direito constitucional brasileiro: discriminação de facto, teoria do impacto desproporcional e ações afirmativas. In: FERES JUNIOR, J.; ZONINZEN, J. (Orgs.). Ação afirmativa no ensino superior brasileiro universitário. Belo Horizonte: UFMG, 2008.

SOARES, D. A escolha profissional do jovem ao adulto. São Paulo: Summus Editorial, 2002.

SOARES-LUCCHIARI, D. Uma abordagem genealógica a partir do genoprofissiograma e do teste dos três personagens. In: LEVENFUS, R. e cols (Org.). Psicodinâmica da escolha profissional. Porto Alegre: Artes Médicas, 1997. p.135-160.

SOARES, A,; DEL PRETTE, Z. Habilidades sociais e adaptação à universidade: convergências e divergências dos constructos. Análise psicológica, v.33, n.2, p.139-151. 2015.

SOARES, A.; FRANCISCHETTO, V.; DUTRA, B.; MIRANDA, J.; NOGUEIRA, C.; LEME, V.; ARAUJO, A.; ALMEIDA, L. O impacto das expectativas na adaptação acadêmica dos estudantes no Ensino Superior. Revista: Psico-USF, v. 19, n.1, p.49-60. 2014. 
SOBRINHO, J. Educação superior: bem público, equidade e democratização. Revista de avaliação da educação superior, v.18, n.1, p.107-126. 2013.

SOBROSA, G., OLIVEIRA, C., SANTOS, A. \& DIAS, A. Influências percebidas na escolha profissional de jovens provenientes de classes socioeconômicas desfavorecidas. Psicologia em Revista, n.21 (2), p.314-333. 2015.

STANK, S., ROTH, S., MONTEIRO, S. \& MAFFEI, A. Influências familiares na escolha profissional. In: II Congresso de Pesquisa e Extensão da FSG, Caxias do Sul, 2014.

WAGNER, A.; PREDEBON, J. \& FALCKE, D. Transgeracionalidade e educação: como se perpetua a família? In: WAGNER, A. (Org). Como se perpetua a família? A transmissão dos modelos familiares. Porto Alegre: EDIPUCRS, 2005. p. 93-105.

WAGNER, A., TRONCO, C., GONÇALVES, J., DEMARCHI, K. \& LEVANDOWSKI, D. Projetos para os filhos e estratégias de socialização: a perspectiva de pais e mães. Psicol. Soc., n.24 (1), p.122-129. 2012.

ZORZO, C.M; SILVA, L.D; POLENZ, T. Buscando a permanência do aluno na universidade: reopção de curso. In: IV seminário de pesquisa em educação região sul: na contracorrente da universidade operacional. Florianópolis, 2002. 
Anexo A

Tabela de sujeitos

\begin{tabular}{|c|c|c|c|c|}
\hline Participante & Idade & Curso & $\begin{array}{l}\text { Escolaridade dos } \\
\text { pais }\end{array}$ & $\begin{array}{l}\text { Ocupação } \\
\text { dos pais }\end{array}$ \\
\hline Nathalia & 23 & Ciências Biológicas & $\begin{array}{l}\text { Pai - ensino } \\
\text { médio completo }\end{array}$ & $\begin{array}{l}\text { Mãe - dona de } \\
\text { casa }\end{array}$ \\
\hline & & & $\begin{array}{l}\text { Mãe - ensino } \\
\text { médio completo }\end{array}$ & $\begin{array}{l}\text { Pai - auxiliar } \\
\text { administrativo }\end{array}$ \\
\hline Rafael & 28 & Engenharia & $\begin{array}{l}\text { Pai - ensino } \\
\text { fundamental } \\
\text { completo } \\
\text { Mãe-ensino } \\
\text { fundamental } \\
\text { completo } \\
\end{array}$ & $\begin{array}{l}\text { Mãe-do lar } \\
\text { Pai-marceneiro } \\
\text { aposentado }\end{array}$ \\
\hline Luiza & 24 anos & Geografia & $\begin{array}{l}\text { Mãe - ensino } \\
\text { fundamental } \\
\text { incompleto } \\
\text { Pai - não soube } \\
\text { informar }\end{array}$ & $\begin{array}{l}\text { Mãe } \\
\text { empregada } \\
\text { doméstica } \\
\text { Pai - não soube } \\
\text { informar }\end{array}$ \\
\hline Antonia & 21 anos & Engenharia & $\begin{array}{l}\text { Pai-ensino } \\
\text { fundamental } \\
\text { incompleto } \\
\text { Mãe-ensino } \\
\text { fundamental } \\
\text { incompleto }\end{array}$ & $\begin{array}{l}\text { Pai-pedreiro } \\
\text { Mãe } \\
\text { Empregada } \\
\text { doméstica }\end{array}$ \\
\hline Luciana & 25 anos & Psicologia & $\begin{array}{l}\text { Pai-analfabeto } \\
\text { Mãe-ensino } \\
\text { médio completo }\end{array}$ & $\begin{array}{l}\text { Pai-pipoqueiro } \\
\text { Mãe-camareira }\end{array}$ \\
\hline Julia & 21 anos & Desenho Industrial & $\begin{array}{l}\text { Pai-ensino } \\
\text { superior completo } \\
\text { Mãe-ensino } \\
\text { médio completo }\end{array}$ & $\begin{array}{l}\text { Mãe- } \\
\text { desempregada } \\
\text { Pai - músico e } \\
\text { professor de } \\
\text { música }\end{array}$ \\
\hline Gisele & 22 anos & Psicologia & $\begin{array}{l}\text { Pai-ensino médio } \\
\text { completo } \\
\text { Mãe-ensino } \\
\text { médio completo }\end{array}$ & $\begin{array}{l}\text { Pai - } \\
\text { optometrista } \\
\text { Mãe - } \\
\text { microempresária }\end{array}$ \\
\hline Marcelo & 20 anos & $\begin{array}{l}\text { Relações } \\
\text { Internacionais }\end{array}$ & $\begin{array}{l}\text { Mãe - ensino } \\
\text { médio completo } \\
\text { Pai - ensino } \\
\text { superior completo }\end{array}$ & $\begin{array}{l}\text { Mãe - personal } \\
\text { organizer } \\
\text { Pai - advogado }\end{array}$ \\
\hline
\end{tabular}


Anexo B

Roteiro de entrevista

Dados da família

Genoprofissiograma - ocupação e escolaridade

PROJETO DE VIDA E PROJETO EDUCACIONAL

Como foi a escolha pelo ensino superior- alguém participou com você dessa escolha?

O que significa estar cursando o ensino superior?

Que referencias você tinha sobre esse curso ou carreira?

Como foi ingressar no ensino superior - o que isso significou - quais foram os momentos mais difíceis - como você lidou com eles - quem te ajudou nesses momentos?

E os momentos mais fáceis/agradáveis/prazerosos?

O que você espera do seu futuro? Como essa formação se encaixa no projeto que você tem para sua vida?

\section{TRANSMISSAO GERACIONAL}

Qual a importância que sua família dá à educação?

Sua família apoia sua formação? De que forma?

Quanto a sua família considera importante ter uma formação no ensino superior?

De que forma sua família investiu em seus estudos até hoje?

Que outros valores você acha que sua família lhe transmitiu ou desejaria transmitir?

PROGRAMAS SOCIAIS DE INSERÇÃO

O que você entende por programas de inserção social? O que você sabe/conhece sobre isso?

Você já participou de programas de inserção social. Quais.

Que importância você atribui a esses programas.

Você sabe se dentro da sua comunidade ou bairro existe algum programa de inserção social

Você acha que um jovem universitário poderia se beneficiar com um programa desses? De que tipo?

O QUE VOCÊ PODERIA ACRESCENTAR? DEIXEI DE PERGUNTAR ALGO? QUER FALAR MAIS SOBRE ALGUMA COISA? 
Anexo C

Termo de consentimento livre e esclarecido

Pontifícia Universidade Católica do Rio de Janeiro

Programa de Pós-Graduação em Psicologia Clínica

Departamento de Psicologia

Pesquisa: Projeto educativo de jovens com perfil socioeconômico filantrópico:

o papel da família

Pesquisadora: Roberta Magacho Rodrigues

Tel.: (21) 99717-7976 e-mail: r.magacho@gmail.com

\section{TERMO DE CONSENTIMENTO LIVRE E ESCLARECIDO}

$\mathrm{Eu}$, (nome do sujeito da pesquisa), estou sendo convidado a participar de um estudo denominado Projeto educativo de jovens com perfil socioeconômico

filantrópico: o papel da família, cujo objetivo é Investigar a percepção do jovem universitário de perfil filantrópico sobre o papel da família no seu projeto educacional.

Estou ciente de que minha privacidade será respeitada, ou seja, meu nome ou qualquer outro dado ou elemento que possa, de qualquer forma, me identificar, será mantido em sigilo.

Também fui informado de que posso me recusar a participar do estudo, ou retirar meu consentimento a qualquer momento, sem precisar justificar, e de, por desejar sair da pesquisa, não sofrerei qualquer prejuízo à assistência que venho recebendo.

Estou ciente de que será assegurada a assistência durante toda pesquisa, bem como me é garantido o livre acesso a todas as informações e esclarecimentos adicionais sobre o estudo e suas conseqüências, enfim, tudo o que eu queira saber antes, durante e depois da minha participação.

Enfim, tendo sido orientado quanto ao teor de todo o aqui mencionado e compreendido a natureza e o objetivo do já referido estudo, manifesto meu livre consentimento em participar, estando totalmente ciente de que não há nenhum valor econômico, a receber ou a pagar, por minha participação.

Assinatura: 